\title{
A COMPARATIVE STUDY OF THE THREE PRINCIPAL REGIONS OF THE SPINAL CORD IN A SERIES OF MAMMALS
}

\author{
PEARL BRIGGS BULLARD
}

From the Laboratory of Anatomy, Tulane University of Louisiana

TWENTY-FIVE FIGURES

This paper presents some observations based on the study of transverse sections of the three principal regions (intumescentia cervicalis, intumescentia lumbalis, and middle of pars thoracalis) of the spinal cord in a series of twenty-four mammals. An outline drawing of a transverse section of the cords in each region is included together with tables of measurements showing variations in dimension and structure of the cords in the different mammals.

\section{MATERIAL AND METHODS}

In most cases one representative only of a species of mammal was studied. Hence all error due to individual variation is included in this work. An average taken from the study of a large number of individuals of each species would obviously be of greater value. In so far as was possible to ascertain, all animals used were normal. A few of the specimens were kindly furnished by Professor Hardesty with the sections ready for study. The method by which they had been prepared, and which was used for the remaining specimens of the list is, very briefly, as follows. 
Most of the spinal cords were removed entire from the vertebral columns as soon after the death of the animal as possible and placed in a 10 per cent solution of formalin. After fixation a segment through each of the enlargements (cervical and lumbar) and the smallest portion of the thoracic region was cut from the cord. The blocks which were taken from the sixth cervical, the eighth thoracic, and the third lumbar segments were mordanted five to ten days in Muller's fluid, embedded in celloidin, and sections cut at 30 micra. The sections were stained by Pal's modification of the Weigert method for medullated nerve fibers.

Drawings. The figures were made in outline by means of the Edinger projection apparatus set for a magnification of eight diameters. They are not intended to present detail of structure but are of value in comparing the form of the several components of the different cords. What little detail is given, however, was obtained with the compound microscope (Leitz, Objective 2, Ocular 3). In the case of the lumbar regions of the ox and of the horse, one side of the largest segment of which was slightly injured in removing the cord, bilateral symmetry was assumed and the injured side was reconstructed from the intact half. With the exception of the lumbar region of the elephant which I was unable to obtain, the three drawings from the cord of each animal in the series is complete.

Tables. Data obtained for use in making the numerous general comparisons of the structures of the spinal cord is accumulated in the following tables with the animals arranged according to body weight. Table 1 gives a complete list of the animals with body weights. The underscored figures are true body weights of the animals, the others approximate. Tables 2, 3, and 4 record for each region certain measurements taken according to the scheme shown in text figure $A$ the lines in which indicate the extent and direction of each measurement. The numbers of the lines in this figure correspond to like numbers in the tables. In all cases measurements of each half of the cord were taken and the average recorded after dividing by eight, the magnification represented by the drawings. Table 5 is constructed from 
the data in tables 2,3 , and 4 and is described in the discussion of it. Table 6 records the exact areas of the several components of the cord as obtained by tracings of the drawings with the Amsler planimeter. Separate readings were taken for the area of the grey figure, the area of the dorsal funiculus, and the total area. Other measurements were obtained by computing differences. Each tracing with the planimeter was taken three times and the average computed to minimize mechanical errors. The

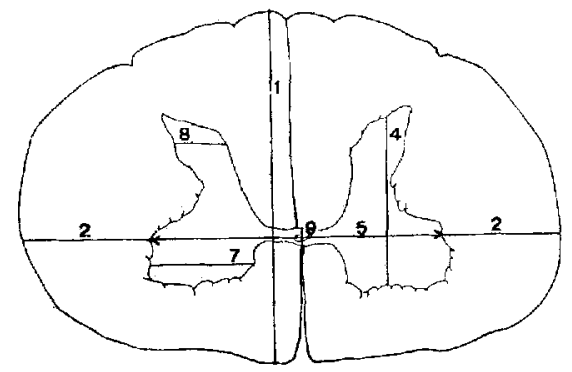

Text figure A. Outline of a section of the spinal cord with lines, numbered, indicating the extent and direction of each of the measurements taken of the different sections of the various spinal cords dealt with. These measurements are recorded in tables 2,3 , and 4 . The numbers of the lines correspond to like numbers in the columns of the tables: 1 , dorso-ventral diameter; 2 , lateral diameter; 4 , thickness of grey figure; 5 , width of grey figure; $\gamma$, width of ventral horn; 8 , width of dorsal horn; 9 , width of grey commissure.

average of the three readings, which were in terms of square centimeters and fractions of square centimeters including vernier readings, were reduced by sixty-four, the square of the magnification. The actual areas of the specimens thus obtained are here recorded in terms of square millimeters. For the sake of convenience, I have selected certain data from table 6 and compiled the tables of ratios, 7, 8a, and $8 \mathrm{~b}$. 


\section{TABLE 1}

Table 1 gives the mammals used arranged in series in order of their absolute and approximate body weights. In case of certain of the specimens, obtained some years ago by Professor IIardesty and some obtained since, the body weight was not determined and here had to be estimated. The underscored weights are absolute weights, the others are approximate.

\begin{tabular}{|c|c|c|}
\hline & KILOS & POUNDS \\
\hline Elephant (Elephas indicus) ............. & $3,628.736$ & 8000 \\
\hline Horse (Equus caballus) ................ & 566.990 & 1250 \\
\hline Ox (Bos taurus) $\ldots \ldots \ldots \ldots \ldots \ldots \ldots \ldots$ & 430.910 & 950 \\
\hline Brown bear (Ursus americanus) ........... & 136.077 & 300 \\
\hline Hog (Sus serofa $) \ldots \ldots \ldots \ldots \ldots \ldots \ldots$ & 68.038 & 150 \\
\hline $\operatorname{Man}($ Tomo sapiens) $\ldots \ldots \ldots \ldots \ldots \ldots$ & 72.574 & 160 \\
\hline Sheep (Ovis aries) $\ldots \ldots \ldots \ldots \ldots \ldots \ldots$ & 34.019 & 75 \\
\hline Kangaroo (Macropus giganteus) ........... & & \\
\hline Black crested ape (Macacus inuus) ........ & 5.216 & \\
\hline Dog (Canis familiaris) . . . . . . . . . . & $\overline{5.000}$ & \\
\hline Gray fox (Urocyon cinero-argentatus).. & $\overline{3.940}$ & \\
\hline Lynx (Felis rufus) . . . . . . . . . . . & 3.050 & \\
\hline Raccoon (Procyon loctor) ......... & & \\
\hline Rhesus monkey (Macacus rhosus) . . . . . . . & 2.720 & \\
\hline Opossum (Didelphys Virginiana)......... & & \\
\hline Cat (Felis domestica)........... & 2.300 & \\
\hline Spider monkey (Ateles paniscus) ...... & $\overline{1.650}$ & \\
\hline Java monkey (Semnopitheous maurus). . . & & \\
\hline Rabbit (Lepus cuniculus) ............. & 1.560 & \\
\hline Agouti (Dascyprocta agouti) ........... & 1.350 & \\
\hline Guinea-pig (Cavia copaya)............. & .610 & \\
\hline Gray rat (Mus Norvegicus). . . . . . . . . . . & .500 & \\
\hline White mouse (Mus musculus, albus) ...... & .027 & \\
\hline Bat (Nyctinomus brasiliensis nasutus) .... & .016 & \\
\hline
\end{tabular}




\section{TABLE 2}

Measurements of cervical region in millimelers. Table 2 includes measurements of transverse sections from the cervical enlargement. The numbers in the heads of the columns correspond to the lines of measurement so numbered in text figure $A$, and the figures record actual size of the sections.

\begin{tabular}{|c|c|c|c|c|c|c|c|c|c|}
\hline A NIMAL & 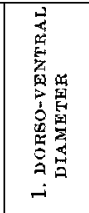 & 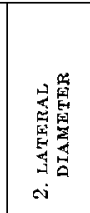 & 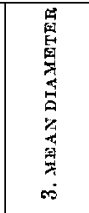 & 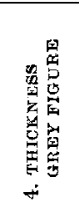 & 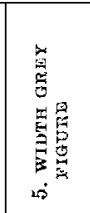 & 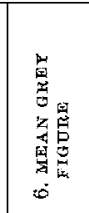 & 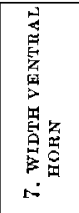 & 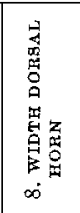 & 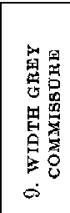 \\
\hline Elephant. & 17.06 & 29.78 & 23.42 & 8.21 & 13.68 & 10.94 & 6.00 & 4.43 & 1.12 \\
\hline Horse.... & 13.43 & 23.28 & 18.35 & 7.28 & 8.81 & 8.04 & 4.00 & 2.50 & 0.68 \\
\hline $\mathrm{Ox} \ldots$ & 11.15 & 17.85 & 14.50 & 5.56 & 7.18 & 6.37 & 3.84 & 2.60 & 0.56 \\
\hline Bear. & 11.06 & 13.65 & 12.35 & 5.87 & 7.75 & 6.81 & 3.37 & 1.60 & 1.12 \\
\hline Hog. & 9.71 & 11.00 & 10.35 & 5.18 & 4.00 & 4.59 & 2.62 & 1.18 & 0.43 \\
\hline Man.... & 8.93 & 13.81 & 11.37 & 4.25 & 7.12 & $5: 68$ & 2.75 & 1.37 & 0.62 \\
\hline Sheep...... & 8.92 & 11.18 & 10.05 & 4.87 & 5.12 & 4.99 & 2.78 & 1.85 & 0.75 \\
\hline Kangaroo.... & 7.50 & 8.84 & 8.17 & 3.58 & 3.12 & 3.35 & 1.43 & 1.75 & 0.87 \\
\hline Ape........ & 6.60 & 7.71 & 7.15 & 3.62 & 3.62 & 3.62 & 1.82 & 1.12 & 0.62 \\
\hline Dog $\ldots . . .$. & $\overline{5} .21$ & 7.81 & 6.51 & 3.06 & 4.87 & 3.96 & 2.10 & 1.12 & 0.31 \\
\hline Fox......... & 7.73 & 7.78 & 7.57 & 3.87 & 3.46 & 3.66 & 1.81 & 1.03 & 0.62 \\
\hline Lynx..... & 9.43 & 10.71 & 10.07 & 4.98 & 5.87 & 5.42 & 2.62 & 1.60 & 0.50 \\
\hline Raccoon........ & 7.37 & 7.78 & 7.57 & 4.31 & 3.65 & 3.98 & 1.50 & 1.28 & 0.56 \\
\hline Rhesus monkey. & 4.81 & 6.50 & $5: 65$ & 3.00 & 2.93 & 2.96 & 1.75 & 1.25 & 0.56 \\
\hline Opossum ....... & 4.62 & 6.15 & 5.38 & 2.62 & 3.06 & 2.84 & 1.43 & 1.21 & 0.37 \\
\hline Cat............ & 5.90 & 7.06 & 6.48 & 3.43 & 3.37 & 3.40 & 1.75 & 1.31 & 0.50 \\
\hline Spider monkey.. & $\tilde{5} .68$ & 7.00 & 6.34 & 3.70 & 4.12 & 3.91 & 1.84 & 1.59 & 0.62 \\
\hline Java monkey.... & 5.68 & 6.31 & 5.99 & 3.75 & 3.25 & 3.50 & 1.50 & 1.06 & 1.12 \\
\hline Rabbit....... & 4.60 & 5.59 & 5.09 & 2.89 & 4.10 & 3.39 & 1.43 & 1.01 & 1.12 \\
\hline Agouti..... & 6.71 & 6.43 & 6.57 & 3.59 & 3.25 & 3.42 & 1.50 & 1.10 & 0.37 \\
\hline Guinea-pig. & 2.87 & 4.06 & 3.46 & 1.93 & 2.18 & 2.05 & 1.12 & 0.81 & 0.43 \\
\hline Rat........ & 2.90 & 4.50 & 3.70 & 1.87 & 2.84 & 2.35 & 1.18 & 0.87 & 0.43 \\
\hline Mouse... & 1.48 & 2.56 & 2.02 & 1.09 & 1.68 & 1.38 & 0.78 & 0.75 & 0.25 \\
\hline Bat...... & 1.31 & 2.93 & 2.12 & 1,25 & 1.93 & 1.59 & 0.93 & 0.87 & 0.15 \\
\hline
\end{tabular}


TABLE 3

Measurements of thoracic region in millimeters. Table 3 recards measurements of transverse sections from the thoracic region, taken as those recorded in table 2 .

\begin{tabular}{|c|c|c|c|c|c|c|c|c|c|}
\hline A NIMAL & 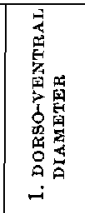 & 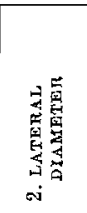 & 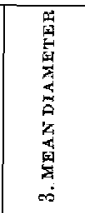 & 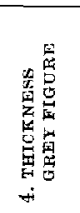 & 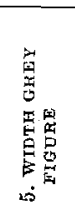 & 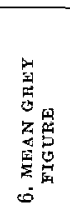 & 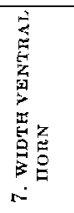 & 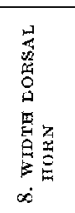 & 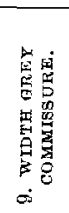 \\
\hline Elephant.......... & 14.65 & 18.56 & 16.60 & 5.71 & 4.68 & 5.19 & 1.10 & 1.75 & 0.75 \\
\hline Horse............ & 12.25 & 13.25 & 12.75 & 5.50 & 3.12 & 3.81 & 1.18 & 1.21 & 0.68 \\
\hline $\mathrm{Ox} \ldots \ldots \ldots \ldots$ & 9.87 & 11.18 & 10.52 & 3.85 & 3.00 & 3.42 & 1.01 & 1.14 & 1.65 \\
\hline Bear........... & 6.87 & 8.12 & 7.49 & 2.31 & 2.81 & 2.56 & 0.84 & 0.87 & 1.18 \\
\hline Hog. . . . . . . . & 7.00 & 7.56 & 7.28 & 3.12 & 1.68 & 2.40 & 0.62 & 0.53 & 1.12 \\
\hline $\operatorname{Man} \ldots . . . \ldots \ldots$ & 7.31 & 8.50 & 7.90 & 2.68 & 2.43 & 2.55 & 0.93 & 0.50 & 0.37 \\
\hline Sheep.............. & 6.31 & 6.62 & 6.46 & 3.12 & 1.87 & 2.49 & 0.56 & 0.62 & 1.06 \\
\hline Kangaroo.......... & 6.81 & 7.15 & 6.98 & 2.87 & 1.56 & 2.21 & 0.50 & 0.56 & 1.31 \\
\hline Ape......... & 4.15 & 4.68 & 4.41 & 1.75 & 1.18 & 1.46 & 0.32 & 0.87 & 0.56 \\
\hline Dog... & 3.76 & 4.59 & 4.17 & 1.62 & 2.09 & 1.85 & 0.65 & 0.53 & 0.56 \\
\hline Fox.... & 5.15 & 5.06 & 5.10 & 2.18 & 1.25 & 1.71 & 0.46 & 0.26 & 0.23 \\
\hline Lynx......... & 5.35 & 6.50 & 5.92 & 2.12 & 1.87 & 1.99 & 0.64 & 0.71 & 1.18 \\
\hline Raccoon...... & 4.62 & 4.87 & 4.74 & 2.03 & 1.15 & 1.59 & 0.40 & 0.53 & 1.00 \\
\hline Rhesus monkey. & 3.37 & 4.93 & 4.15 & 1.37 & 1.43 & 1.40 & 0.40 & 0.62 & 0.93 \\
\hline Opossum....... & 3.60 & 3.93 & 3.76 & 1.75 & 1.18 & 1.46 & 0.16 & 0.43 & 0.56 \\
\hline 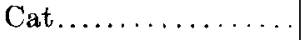 & 4.18 & 4.86 & 4.52 & 1.78 & 1.75 & 1.76 & 0.50 & 0.62 & 0.56 \\
\hline Spider monkey.. & 4.12 & 4.12 & 4.12 & 2.31 & 1.18 & 1.74 & 0.28 & 0.43 & 1.12 \\
\hline Java monkey... & 3.71 & 3.71 & 3.71 & 1.96 & 0.68 & 1.32 & 0.37 & 0.25 & 1.37 \\
\hline Rabbit....... & 3.84 & 4.53 & 4.18 & 1.93 & 1.62 & 1.77 & 0.64 & 0.56 & 0.75 \\
\hline Agouti.... & 5.12 & 5.37 & 5.24 & 2.31 & 1.18 & 1.74 & 0.50 & 0.56 & 0.43 \\
\hline Guinea-pig. . & 2.78 & 2.87 & 2.82 & 1.78 & 1.12 & 1.45 & 0.45 & 0.65 & 0.31 \\
\hline Rat........ & 2.81 & 2.62 & 2.71 & 1.75 & 0.87 & 1.31 & 0.25 & 0.34 & 0.37 \\
\hline Mouse.... & 1.31 & 1.56 & 1.43 & 0.84 & 0.68 & 0.76 & 0.28 & 0.43 & 0.37 \\
\hline Bat.... & 1.28 & 1.59 & 1.43 & 1.00 & 1.25 & 1.12 & 0.31 & 0.71 & 0.25 \\
\hline
\end{tabular}


TABLE 4

Measurements of lumbar region in millimeters. Table 4 records measurements of transverse sections from the lumbar region, laken as those recorded in table 2 .

\begin{tabular}{|c|c|c|c|c|c|c|c|c|c|}
\hline ANIMAL & 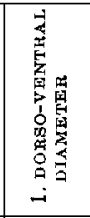 & 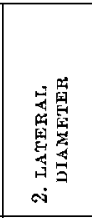 & 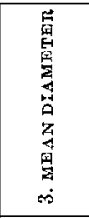 & 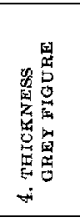 & 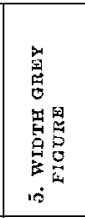 & 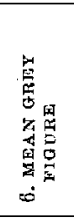 & 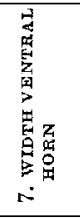 & 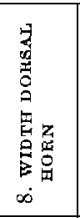 & 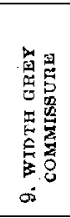 \\
\hline IIorse... & 13.12 & 21.71 & 17.41 & 7.51 & 10.90 & 9.21 & 5.31 & 3.71 & 0.50 \\
\hline$O \times \ldots \ldots$ & 9.18 & 16.00 & 12.59 & 5.84 & 9.00 & 7.42 & 3.75 & 3.37 & 0.50 \\
\hline Bear... & 8.93 & 10.46 & 9.69 & 5.00 & 5.87 & 5.43 & 2.83 & 1.65 & 0.75 \\
\hline Hog. . . & 7.56 & 9.56 & 8.56 & 3.68 & 4.75 & 4.21 & 1.62 & 1.40 & 0.68 \\
\hline Man.... & 8.53 & 9.50 & 9.01 & 4.93 & 5.37 & 5.15 & 2.50 & 1.81 & 0.62 \\
\hline Sheep..... & 7.29 & 10.31 & 8.80 & 4.37 & 5.50 & 4.93 & 2.71 & 2.10 & 0.62 \\
\hline Kangaroo. . & 8.45 & 10.12 & 9.28 & 4.65 & 4.25 & 4.45 & 2.65 & 2.00 & 0.56 \\
\hline Ape....... & 4.92 & 6.28 & 5.60 & 3.00 & 4.25 & 3.67 & 1.90 & 1.43 & 0.37 \\
\hline Dog. & 4.75 & 6.34 & 5.54 & 3.21 & 4.06 & 3.63 & 2.12 & 1.32 & 0.50 \\
\hline Fox. & 6.31 & 7.12 & 6.71 & 3.81 & 3.81 & 3.81 & 1.68 & 1.18 & 0.56 \\
\hline Lynx... & 7.81 & 9.65 & 8.73 & 5.12 & 5.78 & 5.45 & 2.45 & 1.67 & 033 \\
\hline Raccoon....... & 6.21 & 6.81 & 6.51 & 3.71 & 4.50 & 4.10 & 2.09 & 1.43 & 0.71 \\
\hline Rhesus monkey. & 4.50 & 5.81 & 5.15 & 3.06 & 3.37 & 3.21 & 1.65 & 1.25 & 0.50 \\
\hline Opossum....... & 4.51 & 5.56 & 5.03 & 2.93 & 3.12 & 3.02 & 1.76 & 1.46 & 0.71 \\
\hline Cat.......... & 5.31 & 6.43 & 5.87 & 3.43 & 3.50 & 3.46 & 1.75 & 1.43 & 0.37 \\
\hline Spider monkey. & 5.46 & 5.56 & $5: 51$ & 3.50 & 3.87 & 3.68 & 1.93 & 1.78 & 0.62 \\
\hline Java monkey... & 4.75 & 5.75 & 5.25 & 3.62 & 4.06 & 3.84 & 1.87 & 1.37 & 0.87 \\
\hline Rabbit........ & 4.02 & 6.14 & 5.08 & 2.65 & 4.12 & 3.38 & 1.89 & 1.25 & 0.56 \\
\hline Agouti...... & 5.90 & 6.87 & 6.38 & 3.75 & 5.06 & 4.40 & 2.37 & 1.75 & 0.75 \\
\hline Guinea-pig... & 2.85 & 3.87 & 3.36 & 1.96 & 2.37 & 2.16 & 1.16 & 1.15 & 0.31 \\
\hline Rat.......... & 2.59 & 4.31 & 3.45 & 1.71 & 2.87 & 2.29 & 1.31 & 0.87 & 0.35 \\
\hline Mouse.... & 1.45 & 2.12 & 1.78 & 1.03 & 1.37 & 1.20 & 0.65 & 0.60 & 0.35 \\
\hline Bat........ & 1.31 & 2.25 & 1.78 & 1.12 & 1.56 & 1.34 & 0.75 & 0.81 & 0.25 \\
\hline
\end{tabular}




\section{OBSERVATIONS}

\section{Common structures}

In glancing over the drawings, one of the first things which attracts attention is the marked similarity of form throughout the series. Each cord is possessed of bilateral symmetry and presents a grey figure in the shape of the letter $H$, at times considerably modified. Each half of the grey figure of the cord has the ventral and dorsal horn, the gelatinous substance of Rolando being found at the apex of the latter. The two sides of the grey figures are connected by a commissure in which is a central canal surrounded by a homogeneous substance (central gelatinous substance) similar in structure to the gelatinous substance of Rolando. The white substance surrounding the grey is divided into a dorsal and a ventro-lateral funiculus by the more or less well marked dorso-lateral sulcus, the line of ingrowth of the dorsal root. The dorso-intermediate sulcus provides an interesting comparison which will be mentioned when the dorsal funiculus is considered. Each section shows a ventral median fissure but not all, in Weigert sections at least, presents a dorsal median septum. The reticular formation, present in all, varies considerably in amount as the drawings show.

\section{Diameters}

Text-books on neurology state that the human spinal cord in each region has a lateral diameter greater than the dorso-ventral. Authorities agree that the greatest difference in these diameters, or in other words, the portion of the cord most flattened dorsoventrally, is the cervical region. Cunningham '09) states that the lumbar region is more nearly circular than the thoracic. Piersol ('10) on the other hand, gives the lumbar region as being more flattened than the thoracic. The measurements for man here given agree with those of Cunningham. However measurements taken from several other specimens in this laboratory agree more nearly with Piersol.

From table 5, which records in the form of a ratio the relative amount of flattening in each region, it is seen that the bat has a 
cord more flatttened in its cervical region than any other animal in the series here studied. This may be accounted for in part by the extensive innervation required by the greatly developed wing musculature.

The thoracic region, in general for all the spinal cords, is flattened dorso-ventrally. In most cases the flattening is much less than in either the cervical or the lumbar region. The cords of the agouti, lynx, and rhesus monkey are peculiar in that they

TABLE 5

Ratio of dorso-ventral to lateral diameter. Table 5 gives the ratios of the dorso-ventral to the lateral diameter oblained by dividing the figures in column 2 , tables 2 , 3, and 4 by those in column 1 of the same tables. That is to say, the dorso-ventral diameter is to the lateral diameter $\alpha s 1$ is to the figures here recorded. In each column the arimals are arranged in the order of the dorso-ventral flattening of the regions of their spinal cords, those showing the greater dorso-ventral flattening being placed first. The ratio for the lumbar region of the elephant is obtained from diameters given by Kopsch, as quoted from Hardesty.

\begin{tabular}{|c|c|c|}
\hline $\begin{array}{l}\text { CERYICAL } \\
1\end{array}$ & $\begin{array}{l}\text { THORACIC } \\
\quad 2\end{array}$ & $\begin{array}{c}\text { I. DMBAR } \\
3\end{array}$ \\
\hline Bat.............2.23 & Rhesus monkcy ...1.46 & $O x \ldots$ \\
\hline Elephant...........1.74 & Elephant . . . . .1.26 & Bat. \\
\hline Horse........ . . . . 1,73 & Bat..........24 & Rat.... \\
\hline Mouse ...........1.72 & $\operatorname{Dog} \ldots \ldots \ldots$ & Horse.............1.65 \\
\hline $0 x \ldots \ldots \ldots \ldots \ldots \ldots 1.69$ & $\operatorname{Lynx} \ldots \ldots \ldots 1,21$ & Rabbit........... 1.52 \\
\hline Rat............55 & Mouse ... . . . . . 1.19 & Elephant. . . . . . 1.52 \\
\hline $\operatorname{Man} \ldots \ldots \ldots \ldots \ldots 1.54$ & Bear..........1.18 & Mouse ... . . . . . . 1.46 \\
\hline Dog . . . . . . . . . . . 1.49 & Rabbit.........1.17 & Sheep.............1.41 \\
\hline Guinea-pig......... 1.41 & Man . . . . . .1.16 & Guinea-pig..........35 \\
\hline Rhesus monkey.......1.35 & Cat.........16 & Dog . . . . . . . . . .1.33 \\
\hline Opossum...........1.33 & Ox. $\ldots \ldots \ldots \ldots 1.13$ & Rhesus monkey ......1.29 \\
\hline Sheep............. 1.25 & Ape........... .1.12 & Ape............ 1.27 \\
\hline Spider monkey .......1.23 & Opossum .......1.09 & $\operatorname{Hog} \ldots \ldots \ldots \ldots \ldots .1 .26$ \\
\hline Bear........... 1.23 & $\mathrm{Hog} \ldots \ldots \ldots \ldots 1.08$ & Lynx . . . . . . . . . . .1.23 \\
\hline Rabbit ....... . . . . 1.21 & Horse. . . . . . . . 1.08 & Opossum......... 1.23 \\
\hline Cat............. & Raceoon.......1.05 & Cat......... $\ldots \ldots \ldots$ \\
\hline Kangaroo......... & Kangaroo.......1.04 & Java monkey . . . . . . 1.21 \\
\hline Ape............ & Agouti........ . . 1.04 & Kangaroo.........1.19 \\
\hline $\operatorname{Lynx} \ldots \ldots \ldots \ldots$ & Sheep.......... 1.04 & Bear.........17 \\
\hline Hog. . . . . . . . & Guinea-pig. ......1.01 & Agouti. . \\
\hline Java monkey..... & Spider monkey . . 1.00 & Fox...... \\
\hline Fox............ & Java monkey.....1.00 & $\operatorname{Man} \ldots . . .$. \\
\hline Raccoon......... & Fox......... 0.98 & Raccoon..........1.09 \\
\hline Agouti, ........... 0.95 & Rat.......... 0.90 & Spider monkey .......1.01 \\
\hline
\end{tabular}


possess greater flattening in the thoracic than in the cervical region, the sections of which latter are approximately circular. Man, bear, and rhesus monkey stand alone in having a cord in which the thoracic region possesses more dorso-ventral flattening than does the lumbar region.

In about half the mammals of the series, including man, the cervical region of the cords shows a greater dorso-ventral flattening than the lumbar region. In the other half the order is reversed, the greater flattening occurring not in the cervical but in the lumbar region. Chief among this latter number are the sheep, rabbit, hog and Java monkey which, as will be noted, have relatively a very small dorsal funiculus. While on the other hand the bat, mouse, and man have greatly flattened cervical regions and very large dorsal funiculi (column 4, table $8 \mathrm{~b}$ ). The shape of the cords in the series varies to such an extent in each region that it is difficult to say that any given cord is of a predominately rounded or flattened form throughout its length. However, from data here given we may say the bat and elephant are types of dorso-ventrally flattened cords while the fox possesses a cord of rounded form.

\section{Enlargements and total area}

As is well known the cervical and lumbar enlargements are the result of a response to the increased demand for innervation made by the extremities. Furthermore, four-footed animals with approximately equally developed extremities have the area of the cervical enlargement greater than that of the lumbar, due largely to the fact that the cervical region is concerned with the innervation of the tissues of the thorax in addition to those of the upper extremity as well as to the fact that this region carries all the fibers connecting the regions below it with the brain. The kangaroo, with its very small anterior extremities, has a lumbar enlargement the total area of which in transverse section is $13.99 \mathrm{sq} . \mathrm{mm}$. greater than the total area of the section of its cervical enlargement (column 1, table 6, and fig. 8, $C$ and $L)$. 
Schmidt ('08) states that the Dipus (laculus), a kangaroolike rodent, has, notwithstanding its relatively small anterior extremities, a cervical enlargement which exceeds the lumbar. He suggests that the size of the cervical enlargement may be due to the relatively more active anterior extremity.

A very striking illustration of the significance of the enlargements is given by Streeter ('03) in a description of the ostrich cord. The ostrich, according to Streeter, has an insignificant cervical enlargement to correspond with the almost functionless wings. The 'lumbar brain,' on the other hand, extends through eleven segments and its transverse section has an average area of $38.5 \mathrm{sq} . \mathrm{mm}$., which is $20.3 \mathrm{sq} . \mathrm{mm}$. greater than the largest area from the cervical enlargement. Hardesty ('05) finds a similar condition in the cord of the emu, a bird closely allied to the ostrich. The ostrich and emu may be taken as examples in the bird family, of a condition present in the kangaroo among mammalia.

Spitzka ('86) states that the bat has an insignificant lumbar enlargement to correspond with the diminutive posterior extremities. The specimen of bat here used (Nyctinomus brasiliensis nasutus) has a well marked enlargement in the lumbar region as well as a large cervical enlargement which furnishes innervation for its powerful wings (figs $24, C$ and $L$ ). Likewise, it is interesting to note, as stated by Cunningham ('09), that in the cetacea, although there are no visible hind limbs there is a well marked lumbar enlargement. In these animals, this enlargement is no doubt required by the large and powerful tail.

\section{The grey substance}

The $H$ shape of the grey figure, described as eharacteristic of the human cord, holds, as is well known, for the great majority of mammals. In the thoracic region of the bear, rhesus monkey, cat, dog, lynx, and spider monkey the $H$ is highly modified ( $T h$ in figs. $4,10,12,14,16,17$ ). In the first five animals the peculiar shape consists in a shortening or flattening of the dorsal horns and a relatively very wide grey commissure. The almost complete absence of the dorsal horns in these animals 
TABLE 6

Areas of transwerse sections in square millimeters. Table 6 records the total areas in square millimeters of the transverse sections from the different regions of the spinal cords of the animals given and actual areas of the portions of the transverse sections as indicoted in the headings of the columns.

\begin{tabular}{|c|c|c|c|c|c|c|}
\hline ANIMAL & REGION & $\begin{array}{c}1 \\
\text { TOTAL } \\
\text { A REA }\end{array}$ & $\begin{array}{c}2 \\
\text { ARTA OF } \\
\text { GREY } \\
\text { FIGCRE }\end{array}$ & $\begin{array}{c}3 \\
\text { AKEA OF } \\
\text { DOHSAL } \\
\text { FUNICULUS }\end{array}$ & $\begin{array}{c}4 \\
\text { ATIEA OF } \\
\text { ANTERO- } \\
\text { LATERAL } \\
\text { FUNICULUS }\end{array}$ & $\begin{array}{c}5 \\
\text { TOTAL AREA } \\
\text { OF WHTTE } \\
\text { S UBSTANCE }\end{array}$ \\
\hline \multirow{3}{*}{ Elephant......... } & $\mathrm{C}$. & 429.68 & 74.06 & 100.00 & 255.62 & 355.62 \\
\hline & $\begin{array}{l}\text { T. } \\
\text { L. }\end{array}$ & 224.06 & 16.40 & 40.93 & 166.73 & 207.66 \\
\hline & C. & 262.96 & 44.53 & 47.34 & 171.09 & 218.43 \\
\hline \multirow[t]{3}{*}{ Horse. } & $\mathrm{T}$. & 131.25 & 14.06 & 15.15 & 102.04 & 117.19 \\
\hline & L. & 233.35 & 62.50 & 51.56 & 119.29 & 170.85 \\
\hline & C. & 167.81 & 36.87 & 29.06 & 101.88 & 130.94 \\
\hline \multirow[t]{3}{*}{$O x \ldots \ldots \ldots \ldots \ldots$} & $\mathrm{T}$. & 85.93 & 9.37 & 9.68 & 66.88 & 76.56 \\
\hline & I. & 132.03 & 39.53 & 21.87 & 70.63 & 92.50 \\
\hline & C. & 120.15 & 29.92 & 20.70 & 69.53 & 90.23 \\
\hline \multirow[t]{3}{*}{ Bear. } & $\mathrm{T}$. & 44.03 & 4.92 & 7.57 & 31.54 & 39.11 \\
\hline & L. & 74.60 & 21.56 & 16.64 & 36.40 & 53.04 \\
\hline & $\mathrm{C}$. & 85.00 & 18.59 & 11.59 & 54.82 & 66.41 \\
\hline \multirow[t]{3}{*}{ Hog. } & $\mathrm{T}$. & 36.40 & 4.14 & 4.92 & 27.34 & 32.26 \\
\hline & L. & 59.92 & 11.25 & 13.43 & 35.24 & 48.67 \\
\hline & C. & 100.39 & 16.75 & 26.17 & 57.47 & 83.64 \\
\hline \multirow[t]{3}{*}{ Man. } & $\mathrm{T}$. & 52.42 & 5.00 & 14.53 & 32.89 & 47.42 \\
\hline & I. & 65.93 & 21.12 & 15.62 & 29.18 & 44.81 \\
\hline & C. & 82.65 & 21.71 & 11.56 & 49.38 & 60.94 \\
\hline \multirow[t]{3}{*}{ Sheep. } & $\mathrm{T}$. & 35.70 & 4.37 & 3.12 & 28.21 & 31.33 \\
\hline & L. & 61.70 & 20.15 & 9.21 & 32.35 & 41.56 \\
\hline & $\mathrm{C}$. & 55.93 & 10.62 & 9.60 & 35.71 & 45.31 \\
\hline \multirow[t]{3}{*}{ Kangaroo.......... } & $\mathrm{T}$ & 40.46 & 3.75 & 4.21 & 32.50 & 36.71 \\
\hline & L. & 69.92 & 19.68 & 12.42 & 37.82 & 50.24 \\
\hline & $\mathrm{C}$. & 41.64 & 10.23 & 8.82 & 22.59 & 31.41 \\
\hline \multirow[t]{3}{*}{ Ape. . } & $\mathrm{T}$ & 16.25 & 1.56 & 3.12 & 11.57 & 14.69 \\
\hline & L. & 26.09 & 10.54 & 4.60 & 10.95 & 15.55 \\
\hline & $\mathrm{C}$. & 35.46 & 10.93 & 5.78 & 18.75 & 24.53 \\
\hline \multirow[t]{3}{*}{ Dog. } & $\mathrm{T}$ & 14.21 & 2.65 & 1.56 & 10.00 & 11.56 \\
\hline & L. & 26.25 & 9.68 & 3.90 & 12.67 & 16.57 \\
\hline & C. & 45.15 & 11.79 & 6.25 & 27.11 & 33.36 \\
\hline \multirow[t]{3}{*}{ Fox......... } & $T$ & 21.40 & 2.26 & 2.03 & 17.11 & 19.14 \\
\hline & I. & 37.18 & 11.71 & 4.68 & 20.79 & 25.47 \\
\hline & C. & 80.37 & 22.03 & 14.06 & 44.30 & 58.36 \\
\hline \multirow[t]{2}{*}{ Lynx...... } & $\mathrm{T}$. & 27.89 & 3.20 & 3.20 & 21.49 & 24.69 \\
\hline & L. & 53.90 & 21.25 & 9.29 & 23.36 & 32.65 \\
\hline
\end{tabular}


TABLE 6-Continued

\begin{tabular}{|c|c|c|c|c|c|c|}
\hline$\triangle N I M A L$ & REGION & $\begin{array}{c}1 \\
\text { TOTAY } \\
\text { AREA }\end{array}$ & $\begin{array}{c}2 \\
\text { AHEA OF } \\
\text { GREY } \\
\text { FIG ORE }\end{array}$ & $\begin{array}{c}3 \\
\text { AREA OF } \\
\text { DORSAL } \\
\text { FUNTCULUS }\end{array}$ & $\begin{array}{c}4 \\
\text { AREA OF } \\
\text { ANTERO- } \\
\text { LATERAL } \\
\text { FCAICUL CE }\end{array}$ & $\begin{array}{c}\bar{y} \\
\text { TOTAL AREA } \\
\text { OE WHTTE } \\
\text { SUBSTANCE }\end{array}$ \\
\hline & C. & 45.39 & 11.87 & 10.70 & 22.82 & 33.52 \\
\hline \multirow[t]{3}{*}{ Raccoon. } & $T$ & 17.73 & 1.79 & 3.82 & 12.12 & 15.94 \\
\hline & L. & 33.82 & 12.65 & 5.39 & 15.78 & 21.17 \\
\hline & C. & 26.95 & 9.06 & 5.62 & 12.17 & 17.89 \\
\hline \multirow[t]{3}{*}{ Rhosus monkey..... } & $\mathrm{T}$. & 12.81 & 1.56 & 1.54 & 9.71 & 11.25 \\
\hline & L. & 21.87 & 8.43 & 4.37 & 9.07 & 13.44 \\
\hline & C. & 23.90 & 6.40 & 4.68 & 12.82 & 17.50 \\
\hline \multirow[t]{3}{*}{ Opossum. } & $\mathrm{T}$. & 10.78 & 1.56 & 1.56 & 7.66 & 9.22 \\
\hline & L. & 20.85 & 8.04 & 2.50 & 10.35 & 12.81 \\
\hline & C. & 35.31 & 10.56 & 5.70 & 19.05 & 24.75 \\
\hline \multirow[t]{3}{*}{ Cat............. } & $\mathrm{T}$. & 15.15 & 2.10 & 2.93 & 10.12 & 13.05 \\
\hline & L. & 28.20 & 10.46 & 4.92 & 12.82 & 17.74 \\
\hline & C. & 32.81 & 12.03 & 6.25 & 14.53 & 20.78 \\
\hline \multirow[t]{3}{*}{ Spider monkey ...... } & $T$. & 13.90 & 2.18 & 3.12 & 8.60 & 11.72 \\
\hline & I. & 25.00 & 10.85 & 4.53 & 9.62 & 14.15 \\
\hline & C. & 30.46 & 9.37 & 5.46 & 15.63 & 21.09 \\
\hline \multirow[t]{3}{*}{ Java monkey....... } & $\mathrm{T}$ & 11.09 & 1.40 & 1.25 & 8.44 & 9.69 \\
\hline & L. & 23.28 & 11.71 & 2.34 & 9.23 & 11.57 \\
\hline & C. & 21.32 & 6.40 & 2.81 & 12.11 & 14.92 \\
\hline \multirow[t]{3}{*}{ Rabbit.......... } & $\mathrm{T}$. & 13.59 & 2.50 & 1.56 & 9.53 & 11.09 \\
\hline & L. & 20.62 & 7.81 & 2.57 & 10.24 & 12.81 \\
\hline & C. & 35.00 & 8.20 & 6.71 & 20.09 & 26.80 \\
\hline \multirow[t]{3}{*}{ Agouti. } & $\mathrm{T}$ & 21.87 & 2.65 & 3.59 & 15.63 & 19.22 \\
\hline & I. & 34.21 & 15.31 & 4.92 & 13.98 & 18.90 \\
\hline & $\mathrm{C}$. & 9.92 & 3.12 & 1.48 & 5.32 & 6.80 \\
\hline \multirow[t]{3}{*}{ Guinea-pig. } & $\mathrm{T}$. & 6.71 & 1.71 & 1.09 & 3.91 & 5.00 \\
\hline & I. & 9.84 & 4.45 & 1.40 & 3.99 & 5.39 \\
\hline & $\mathrm{C}$. & 11.32 & 4.06 & 1.79 & 5.47 & 7.26 \\
\hline \multirow[t]{3}{*}{ Gray rat.......... } & $\mathrm{T}$. & 6.09 & 1.87 & 1.01 & 3.21 & 4.22 \\
\hline & L. & 9.37 & 3.82 & 1.40 & 4.15 & 5.55 \\
\hline & $\mathrm{C}$. & 3.98 & 1.87 & 0.63 & 1.48 & 2.11 \\
\hline \multirow[t]{3}{*}{ Mouse........... } & $\mathrm{T}$ & 2.08 & 0.78 & 0.31 & 0.94 & 1.25 \\
\hline & I. & 3.43 & 1.56 & 0.70 & 1.17 & 1.87 \\
\hline & $\mathrm{C}$. & 3.59 & 2.18 & 0.41 & 1.00 & 1.41 \\
\hline \multirow[t]{2}{*}{ Bat............ } & $\mathrm{T}$ & 1.71 & 1.32 & 0.12 & 0.27 & 0.39 \\
\hline & L. & 2.96 & 1.56 & 0.48 & 0.92 & 1.40 \\
\hline
\end{tabular}


is quite striking. This condition may be interpreted as a dorsoventral thickening and mesial fusion of the dorsal horns (posterior grey columns) since the gelatineus substance of Rolando and the dorsal horn cells are present as normally. The spider monkey (fig. 17) possesses relatively short ventral or anterior horns and this relative shortening is evident through all three regions of the cord.

In all the animals here studied, with one exception, the width or thickness of the ventral horn in the cervical region exceeds that of the dorsal horn. This exception is in the kangaroo in the cervical region of which, the caput of the dorsal horn is wider than is the ventral horn. This condition in the kangaroo is due, not to a relatively extra wide dorsal horn but to a narrow vertral horn. Because of its small anterior extremities, it is probable that cutaneous innervation may not have decreased to the same extent as the innervation required by the muscles, which receive motor or ventral root-fibers and which have atrophied through greatly lessened use. If such be the case, the retained width of the dorsal horn may be understood in that it contains the cell bodies of association and commissural neurones about which the dorsal root or sensory fibers terminate for purposes of functionally associating different levels and the two sides of the spinal cord with sensations brought into the cervical region.

The lumbar region shows throughout the series the ventral horn to be wider than the dorsal horn (columns 7 and 8 , table 4). However, the average difference in the width of the two horns in the lumbar region for the series is only $0.52 \mathrm{~mm}$. while in the cervical region the average difference is $0.64 \mathrm{~mm}$., the ventral horn being the wider.

The difference in width of the dorsal and ventral horns is in the thoracic region very much less than in either of the other two regions (columns 7 and 8, table 3). In most cases the dorsal horn is somewhat the wider. This is what we should expect since in the thoracic region the musculature is lessened in amount to an extent greater than is the sensory area decreased.

The dorso-ventral width of the grey commissure as taken through the central canal (column 9 , tables $2,3,4$ ), varies through- 
out the series. The average thickness is greater in the thoracic region than in either of the other two regions, being $0.84 \mathrm{~mm}$. in the thoracic, $0.61 \mathrm{~mm}$. for the cervical and $0.54 \mathrm{~mm}$. for the lumbar region. It is noticeably thick in the thoracic regions of the ox, bear, hog, sheep, kangaroo, fox, Java monkey, and rabbit.

Reticular formation. There is considerable variation in the amount of reticular formation as shown in the figures. This reticular network is believed to be formed, at least in part, by a dispersion of the lateral portions of the grey figure (1) by bundles of longitudinally coursing association fibers (fasciculi proprii), (2) by fibers passing out of the grey figure into the white substance and (3) by the fibers from the crossed pyramidal tracts leaving the lateral funiculus and entering the grey figure to terminate about ventral horn cells. However, the lateral pyramidal tract may have little to do with it for the animals which have their pyramidal tract in the dorsal funiculus have the reticular formation as well, often better, marked than do animals which have the pyramidal tract in the lateral funiculus.

Nucleus dorsalis. A nucleus dorsalis (Clarke's column) is well marked in the thoracic region of by far the greater number of animals here studied. In the following six mammals, kangaroo, opossum, agouti, guinea-pig, rat, and mouse the nucleus is not clearly defined. As will be mentioned, the pyramidal tract in each of these animals courses, probably in the dorsal funiculus and it may be that the dorsal position of this tract is in some way associated with the modified appearance of the nucleus dorsalis. These observations are based on the study of Weigert sections in which the cell-bodies are not stained, but the position and usually a very good outline of the cell-body may be seen.

Proportion of grey substance to white. An idea of the relative amount of grey substance as compared with white in the spinal cord is best obtained from a study of the ratios of the absolute areas of the two. Table 7 gives such a ratio for the three regions of the cord of each animal. The area of the grey figure is to the total area of the white substance as 1 is to the figure given in the table. All of the spinal cords, with the exception of 
the mouse and bat, show the lumbar region to contain the largest relative amount of grey substance, while the thoracic contains the smallest relative amount, in each animal. An average of the ratios in the three regions is valuable since it provides a comparison of the relative amounts of white and grey substance through, what we may consider, the entire cord. The average of the ratios in the three regions emphasizes the well known fact that, in general, the smaller the animal, the greater is the proportion of grey substance to white. A glance at the drawings of the cervical and thoracic regions of the elephant (fig. $1, C$ and $T h$ ) and the corresponding regions of the bat (fig. 24, $C$ and Th) show the relatively high proportion of grey substance in the smaller animals.

TABLE 7

Ratio of area of grey substance to area of white substance. Trable 7 records the ratios of grey substance to white substance obtained by dividing the figures in column 2 of table 6 into those of column 5 , table 6 , that is to say, the area of grey substance is to the area of white substance as 1 is to the figures recorded in columns 1,2 , and 3 .

\begin{tabular}{|c|c|c|c|c|}
\hline ANIMAL & $\underset{1}{\text { CERVICAL }}$ & $\begin{array}{c}\text { THORACIC } \\
2\end{array}$ & $\begin{array}{c}\text { LUMBAR } \\
3\end{array}$ & $\begin{array}{l}\text { AVERAGE } \\
4\end{array}$ \\
\hline Elephant................ & 4.8 & 12.6 & & \\
\hline Horse . . . . . . . . . . . . & 4.9 & 8.3 & 2.7 & 5.2 \\
\hline $\mathrm{Ox} \ldots \ldots \ldots \ldots \ldots \ldots \ldots$ & 3.6 & 6.1 & 2.3 & 4.0 \\
\hline Bear. . . . . . . . . . . . & 3.0 & 7.9 & 2.4 & 4.4 \\
\hline $\boldsymbol{H o g} \ldots \ldots \ldots \ldots \ldots \ldots \ldots$ & 3.6 & 7.8 & 4.3 & 5.2 \\
\hline 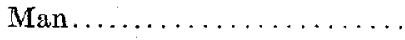 & 5.0 & 9.5 & 2.1 & 5.5 \\
\hline 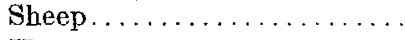 & 2.8 & 7.2 & 2.1 & 4.0 \\
\hline Kangaroo............... & 4.3 & 9.8 & 2.6 & 5.5 \\
\hline Ape $\ldots \ldots \ldots \ldots \ldots \ldots$ & 3.1 & 9.4 & 1.5 & 4.6 \\
\hline Dog $\ldots \ldots \ldots \ldots \ldots \ldots$ & 2.2 & 4.3 & 1.7 & 2.7 \\
\hline Fox $\ldots \ldots \ldots \ldots \ldots \ldots \ldots$ & 2.8 & 8.5 & 2.2 & 4.5 \\
\hline $\mathbf{L y n x} \ldots \ldots \ldots \ldots \ldots \ldots$ & 2.6 & 7.7 & 1.5 & 3.9 \\
\hline 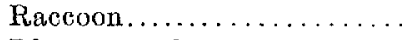 & 2.8 & 8.9 & 1.7 & 4.4 \\
\hline Rhesus monkey ........... & 2.0 & 7.2 & 1.6 & 3.6 \\
\hline 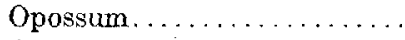 & 2.7 & 5.9 & 1.6 & 3.4 \\
\hline 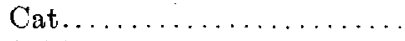 & 2.3 & 6.2 & 1.7 & 3.4 \\
\hline Spider monkey ............ & 1.7 & 5.4 & 1.3 & 2.8 \\
\hline Java monkey .............. & 2.3 & 6.9 & 0.9 & 3.3 \\
\hline 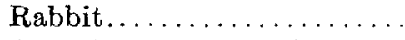 & 2.3 & 4.4 & 1.6 & 2.7 \\
\hline Agouti........ & 3.3 & 7.3 & 1.2 & 3.9 \\
\hline Guinea-pig. .... & 2.2 & 2.9 & 1.2 & 2.1 \\
\hline Rat....... & 1.8 & 2.3 & 1.5 & 1.8 \\
\hline Mousé....... & 1.1 & 1.6 & 1.2 & 1.3 \\
\hline Bat. . . . . . . . & 0.6 & 0.3 & 0.9 & 0.6 \\
\hline
\end{tabular}




\section{White substance}

Dorso-intermediate sulcus. In the kangaroo, raccoon, opossum, and Java monkey, a dorso-intermediate sulcus is clearly present in all three regions (figs. 8, 13,15 and 18). In a much larger number of species it is clearly evident only in the cervical region, man being among this number. In some animals, the ox, sheep and $\operatorname{dog}$, for example, in Weigert preparations, it is not to be seen in any of the regions. In most of the sections, considerable difference is noted between the areas of white substance on either side of this sulcus. The area nearest the dorsal median septum, corresponding to the fasciculus gracilis in man, is composed of relatively small, closely packed axones which give it a darkened appearance in transverse sections stained by the Weigert method. The lateral area which corresponds to man's fasciculus cuneatus, is composed of relatively larger axones. Singer ('81), who describes the origin and position of the fasciculus gracilis in the dog, shows in his drawings no septum between it and the fasciulus cuneatus. It must be that in certain animals the factors which determine whether there shall be an ingrowth of the pial connective tissue to form this sulcus are different during fetal life while the fasciculus gracilis and fasciculus cuneatus are being acquired and becoming medullated. In most cases where the sulcus is wanting, one may observe in the cervical and thoracic regions that the fibers are smaller and more closely accumulated, and that the area is darker, near the dorsal median septum than in the more lateral areas of the dorsal funiculus.

Position of pyramidal tract. Simpson ('02) describes the pyraamidal tract for the dog, cat and monkey as situated in the dorsal part of the lateral funiculus. The guinea-pig and mouse, according to Reverly and Simpson ('10), who confirm the earlier work of Von Bechterew and Von Lenhossek, have the pyramidal tract in the dorsal funiculus. King ('10) has traced the pyramidal tract of the rat into the dorsal funiculus. Spitzka ('86) states that the sheep and ox have no fibers, to be seen macroscopically, which cross from the pyramids in the medulla oblongata into the lateral funiculus. The elephant, according 
to Hardesty ('02), has a part at least of the pyramidal tract situated on either side of the mid-line between the dorsal and ventral lamina of the grey commissure. Believing that it corresponds to the lateral or crossed pyramidal tract in man, he has designated it 'fasciculus cerebro-spinalis internus' (fig. 1, $C$ and Th). Burkholder ('04) describes this tract in the sheep as occupying the same position as in the elephant and has termed it the 'fasciculus cerebro-spinalis internus' after Hardesty. King and Simpson ('10) state that the pyramidal fibers for the sheep are situated in the reticular formation in the lateral aspect of the dorsal horn. The specimen of sheep here studied, as well as the ox, presents in all three regions a structure identical in position to that described by Burkholder (figs. 3 and 7, $C, T h$ and $L$ ). Symington ('08) states that the kangaroo has the pyramidal tract in the dorsal funiculus and the rabbit has the tract in the lateral funiculus.

I have compared sections through the pyramidal decussation in the medulla of the agouti and opossum with those of the rat, mouse and kangaroo, and am of the opinion that the pyramidal tract in the former animals, as well as in the latter, is situated in the dorsal funiculus. The agouti, like the rat, mouse and guinea-pig, is a rodent, while the opossum, being a marsupial, is related to the kangaroo. From an examination of sections through the medulla of the raccoon and of the fox, the pyramidal fibers appear to course in the reticular formation. However, the experimental method is the only trustworthy one for determining the position of any fiber tract.

Comparison of funiculi. As is to be expected, all of the cords here considered have, in each region, a dorsal funiculus which is exceeded in actual area in transverse section by the ventro-lateral funiculus (table 6 ). The comparative size of the funiculi can be best expressed in the form of a ratio. Table 8 ( $a$ and $b$ ) record such ratios for each region, obtained by dividing the area of the ventro-lateral funiculus by that of the dorsal funiculus. It is clear that the higher the ratio, the smaller relatively is the dorsal funiculus. For example, table $8 \mathrm{a}$, column 4 , gives man as having the lowest average ratio, 2.10 , which 
means that the average size of the ventro-lateral funiculus for the three regions is 2.10 times the size of the dorsal funiculus for the three regions. The fox with the highest average ratio, 5.73 , shows therefore relatively the smallest dorsal funiculus of the series.

While the human cord does not show the largest relative size of the dorsal funiculus in either the cervical or the lumbar region, being surpassed in the former by the raccoon and rhesus monkey, in the latter by mouse and rhesus monkey, yet the average of the three regions places man first. In other words, all the other

\section{TABLE 8}

Ratios of dorsal funiculus to ventro-lateral funiculus. Table 8 a has been computed from data in table 6, by dividing the figures in column 4 by those in column 3 , table 6. In other words, the dorsal funiculus is to the ventro-lateral funiculus as 1 is to the figures in columns 1,2 and 3 below. Column 4 records the average ratios of 1, 2 and 3 . The animals are arranged according to body weight.

\begin{tabular}{|c|c|c|c|c|}
\hline ANIMAL & $\underset{1}{\text { CERTICAL }}$ & $\underset{2}{\text { THORACIC }}$ & $\underset{3}{\operatorname{LUMBAR}}$ & $\underset{4}{\text { AVERAGE RATIO }}$ \\
\hline Elephant . . . . . . . . . . & 2.55 & 4.07 & & \\
\hline Horse . . . . . . . . . . & 3.61 & 6.73 & 2.31 & 2.96 \\
\hline 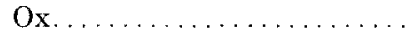 & 3.50 & 6.90 & 3.22 & 4.54 \\
\hline Bear. . . . . . . . . . . . & 3.35 & 4.16 & 2.18 & 3.23 \\
\hline Hog. . . . . . . . . . . . . & 4.72 & 5.55 & 2.62 & 4.29 \\
\hline $\operatorname{Man} \ldots \ldots \ldots \ldots \ldots \ldots$ & 2.19 & 2.26 & 1.86 & 2.10 \\
\hline Sheep. . . . . . . . . . . . & 4.27 & 9.04 & 3.51 & 5.60 \\
\hline 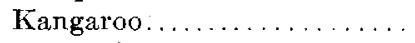 & 3.71 & 7.72 & 3.04 & 4.82 \\
\hline Ape.................. & 2.56 & 3.70 & 2.38 & 2.88 \\
\hline $\operatorname{Dog} \ldots \ldots \ldots \ldots \ldots \ldots$ & 3.24 & 6.41 & 3.24 & 4.29 \\
\hline 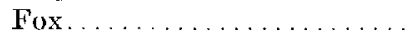 & 4.33 & 8.42 & 4.44 & 5.73 \\
\hline $\operatorname{Lynx} \ldots \ldots \ldots \ldots \ldots \ldots$ & 3.15 & 6.71 & 2.51 & 4.12 \\
\hline Raccoon................. & 2.13 & 3.17 & 2.92 & 2.74 \\
\hline Rhesus monkey ........... & 2.18 & 7.03 & 1.75 & 3.65 \\
\hline Opossum . . . . . . . . . & 2.52 & 4.91 & 4.12 & 3.85 \\
\hline 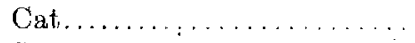 & 3.34 & 3.45 & 2.60 & 3.13 \\
\hline Spider monkey........... & 2.32 & 2.75 & 2.12 & 2.39 \\
\hline Java monkey............ & 2.88 & 6.75 & 3.94 & 4.52 \\
\hline 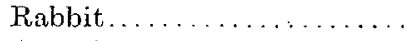 & 4.30 & 6.10 & 3.98 & 4.79 \\
\hline Agouti. . . . . . . . . . . . & 2.99 & 4.35 & 2.84 & 3.39 \\
\hline Guinea-pig . . . . . . . . . & 3.59 & 3.58 & 3.58 & 3.58 \\
\hline Pat. . . . . . . . . . & 3.05 & 3.17 & 2.90 & 3.04 \\
\hline Mouse . . . . . . . . . . . . . . . & 2.34 & 3.03 & $1.67^{\circ}$ & 2.34 \\
\hline 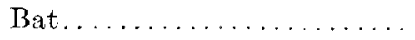 & 2.43 & 2.27 & 1.91 & 2.20 \\
\hline
\end{tabular}


cords in the series have average dorsal funiculi smaller in proportion to the ventro-lateral funiculi than does the human spinal cord. The dorsal funiculus in man is made up, in large part, of ascending axones of spinal ganglion neurones, a large proportion of which connect the cord with the encephalon. The latter reaches its highest development in man and the dorsal funiculus is correspondingly increased in size. We might expect the cervical region in man especially to show a larger ratio for the dorsal funiculus than does the thoracic or lumbar region since

\section{TABLE $8 b$}

Ratios dorsal funiculus to ventro-lateral funiculus. Table 86 records the same data as table 8 a but with the animals arranged according to the relative size of the dorsal funiculus in each region of the cord instead of according to body weight.

\begin{tabular}{|c|c|c|c|}
\hline $\begin{array}{l}\text { CERVICAL } \\
1\end{array}$ & $\underset{2}{\mathrm{THORACIC}}$ & $\underset{3}{\text { LUMBAR }}$ & $\underset{4}{A V E R A G E}$ \\
\hline Raccoon..... & Man $\ldots \ldots \ldots 2.26$ & Mouse.....1.67 & $\operatorname{Man} . . . . . .2 .10$ \\
\hline Rhesus monkey. 2.18 & Bat........2.27 & Rhesus mon- & Bat.........2.20 \\
\hline $\operatorname{Man} \ldots \ldots \ldots \ldots 2.19$ & Spider mon- & key.....1.76 & Mouse.......2.34 \\
\hline Spider monkey . . 2.32 & key......2.75 & Man.......1.86 & Spider mon- \\
\hline Mouse ........... & Mouse......3.03 & $\ldots 1.91$ & key ......2.39 \\
\hline Bat..... & Raceoon ....3.17 & Spider mon- & Raccoon .....2.75 \\
\hline Opossum. & Rat...........17 & key......2.12 & Ape ....... .2.88 \\
\hline Elephant. & .3 .45 & Bear......2.18 & Forse .....2.95 \\
\hline Ape....... & Guinea-pig. 3.58 & Horse ......2.31 & Rat........3.04 \\
\hline Java monkey. & $\ldots 3.70$ & Ape .......2.2.38 & Cat... \\
\hline Agouti........ & lant...4.07 & Lynx. & Bear.........3.23 \\
\hline Rat....... & Bear .......4.16 & $\ldots 2.60$ & Agouti........3.39 \\
\hline Lynx........ & Agouti......4.35 & $\operatorname{Hog} \ldots \ldots \ldots 2.62$ & Guinea-pig. . .3.58 \\
\hline $\operatorname{Dog} \ldots \ldots \ldots$ & Opossum . . .4.91 & Agouti....2.84 & Rhesus mon- \\
\hline Cat......... & Hog.......5.55 & Rat......2.90 & key........3.65 \\
\hline Bear.. & $\ldots 6.10$ & ....2.92 & Opossum ....3.85 \\
\hline .3 .50 & $\ldots 6.41$ & $00,3.04$ & Lynx . . . . . .4.12 \\
\hline Guinea-pig. & $\ldots 6.71$ & $\ldots .3 .22$ & Dog... \\
\hline Horse...... & $\ldots \ldots 6.73$ & $\ldots 3.24$ & Hog. . . . . .4.29 \\
\hline Kangaroo... & Java mon- & Sheep.......3.51 & Java mon- \\
\hline Shecp....... & key.......6.75 & Guinea-pig. 3.58 & key.......4.52 \\
\hline Rabbit.... & $0 x \ldots \ldots \ldots 6.90$ & Java mon- & .4 .54 \\
\hline Fox........ & Rhesu & ......3.94 & Rabbit.... \\
\hline \multirow[t]{4}{*}{$\operatorname{Hog} \ldots \ldots \ldots \ldots 4.72$} & $\ldots .03$ & $\ldots 3.98$ & Kangaroo. . \\
\hline & roo..7. & $\mathrm{m} \ldots 4.12$ & Sheep..... \\
\hline & Fox & $\ldots .44$ & $\ldots .5 .73$ \\
\hline & Sheep. & & \\
\hline
\end{tabular}


the two fasciculi of which it is largely composed contain a large proportion of spino-cerebral fibers ascending from all segments of the cord and thus it must increase in size from below upward. However, column 3, table 8a, shows the lumbar region of the human cord to possess a larger relative size for the dorsal funiculus than either of the other two regions. The pyramidal tract, in the ventro-lateral funiculus, which has its maximum size in the cervical region is one of the principal factors in reducing the relative size of the dorsal funiculus in this region. Another factor in the lumbar enlargement is the large proportion of association fibers in the dorsal fasciculi proprii of the dorsal funiculus.

In those animals in which the crossed pyramidal tracts course in the dorsal, instead of in the lateral funiculus, one would expect a relatively larger area of dorsal funiculus and a resultingly smaller arca in the ventro-lateral funiculus. Reference to these animals in tables $8 \mathrm{a}$ and $8 \mathrm{~b}$ does not show a relatively greater area of the dorsal funiculus (smaller ratio of the ventro-lateral funiculus) to be of distinguishingly constant occurrence. In some cases, agouti, guinea-pig and rat, for example, the ratios for the cervical region are approximately the same as those for the lumbar region in spite of the fact that there are both ascending and descending fibers in the dorsal funiculus which must increase as the cord is ascended.

In all mammals, there is a decrease in the absolute area of the dorsal funiculus in passing from the lumbar to the thoracic region. The horse, ox, bear, sheep, kangaroo, hog and lynx show a very great decrease in the area of the dorsal funiculus from the lumbar to the thoracic region (table 6). The difference in the area of the ventro-lateral funiculus in the two regions of the above animals is very slight. This fact is expressed in another form in columns 2 and 3 , table $8 \mathrm{~b}$. The horse, for example, has in the transverse section of the lumbar region a ventro-lateral funiculus 2.31 times that of the dorsal funiculus, while in the thoracic region, the ventro-lateral funiculus is 6.73 times the dorsal. It is probable that in these animals an especially large number of axones from the dorsal roots of the lumbar region extend up the cord only a short distance and then terminate around cell-bodies in the grey substance. 
The ape and monkeys, as expected from their high position among mammals, show a relatively large dorsal funiculus. The spider monkey, for example, has an avcrage ratio for the three regions of 2.39, that is to say, the dorsal funiculus of the spider monkey is only slightly less than one-half the size of the ventrolateral. The relatively large dorsal funiculus of this animal is explained in part at least by the fact that it possesses an exceptionally long, large and specially functioning tail whose skin area must require a large additional number of ascending axones in the cord. The striking motility and functional control of this tail must mean additional and no doubt a special bundle of pyramidal axones. These latter, descending in the lateral funiculus, render the dorsal funiculus only relatively less large than it would be otherwise.

I am not able to explain why the cord of the raccoon should show such a relatively large dorsal funiculus which, in the cervical region is to the ventro-lateral funiculus as 1 is to 2.13 , being relatively larger in this region than that found in any of the other animals. The upper extremities of the raccoon are somewhat less highly functional than those of the monkey, its tail is relatively no larger and but little more functional than that of the dog or fox and its pyramidal tract does not appear to course in its dorsal funiculus. The mouse and agouti have relatively large dorsal funiculi, due, at least in part, to the fact that they have the crossed pyramidal tract in this funiculus.

Column 4, table 8b, gives the fox as having an average dorsal funiculus less than one-fifth the size of the ventro-lateral. This must mean that he possesses an enormous number of association fibers in the lateral funiculus or that the spino-cerebellar fasciculi are unusually large. It is to be noted that the great variation in relative size of the two funiculi which most of the animals show throughout the three regions is not evident in the fox (table $8 b)$. The acuteness of the fox in reflex action is proverbial and complex reflex activities are anatomically explained on the basis of abundant association fibers (fasciculi proprii). Also, for cerebral muscular control, this animal may have relatively large pyramidal fasciculi. The sheep and rabbit likewise are popu- 
larly known as reflex animals. They stand close to the fox in the small size of the dorsal funiculus as compared with the ventrolateral. It is probable that, in these animals, by far the greater number of dorsal root axones terminate in the grey substance of the cord after a comparatively short course in the dorsal funiculus, thus accounting, in large part, for the small size of the latter. Man and the monkeys, as examples of animals with a highly developed encephalon, have relatively large dorsal funiculi; while the fox, sheep, and rabbit with acute spinal reflexes have very small dorsal funiculi. The relative size of the dorsal and ventrolateral funiculi, however, may be the result of many factors of which we have considered but a few.

This investigation has been carried on under the direction of Prof. Irving Hardesty who kindly furnished much of the material. I am under obligations to him for many helpful suggestions.

\section{LITFRATURE CITED}

Burkholder, J. F. 1904 The anatomy of the brain. Chicago, G. P. Engelhard and Company.

HARDESTY, IRYING 1902 Observations on the medulla spinalis of the elephant with some comparative studies of the intumescentia cervicalis and the neurones of the columna anterior. Jour. Comp. Neur., vol.12, no. 2. 1905. Observations on the spinal cord of the emu and its segmentation. Jour. Comp. Neur., vol. 12, no. 2.

King, Jessie L. 1910 The cortico-spinal tract of the rat. Anat. Rec., vol. 4 , no. 7.

King, J. L., And Simpson, Sutherland 1910 The pyramid decussation in the sheep. 79 Rep. British Assoe. Adv. Sc. Winnipeg.

ReverLy, IDA Z.,ANd Simpson, Sutherland 1910 The cortico-spinal tract in the guinea-pig. 79 Rep. British Assoc. Adv. Sc. Winnipeg.

SChärer, E. A., ANd Symington, J. 1908 Quain's anatomy, vol. 3.

Sснміdт, 1908 Beitrag zum Studium des verhältnisses von Rükenmarksbau und Extremitätencntwicklung. Journal für Psychologie und Neurologie, Bd. 9.

Spitzka, E. C. 1886 The comparative anatomy of the pyramid tract. Journal Comparative medicine and surgery, vol. 7 , no. 1.

Singer, J. 1881 Uber secundäre Degeneration im Rückenmarke des Hundes. Sitzb. der k. Akad. der Wissensch., Bd. 84.

Simpson, Sutherlaxd 1902 The pyramidal tract in the eat, dog, and monkey. Proceedings Scottish Microscopical Society, vol. 3.

Streeter, George L. 1903 The structures of the spinal cord of the ostrich. Amer. Jour. Anat,, vol. 3. 


\section{EXPLANATION OF PLATES}

The plates contain figures representing outline drawings of transverse sections taken from the sixth cervical, eighth thoracic, and third lumbar segments of the spinal cords of the twenty-four mammals named. The drawings were traced from projections of the respective section with the Edinger Drawing Apparatus set for a magnification of eight diameters. They are here reduced one-half and thus are magnified four times. The letter $C$ indicates the cervical region, $T h$, the thoracic, and $L$, the lumbar; F.c.i., fasciculus cerebro-spinalis internus. 
PRINCIPAL REGIONS OF SPINAI, CORD
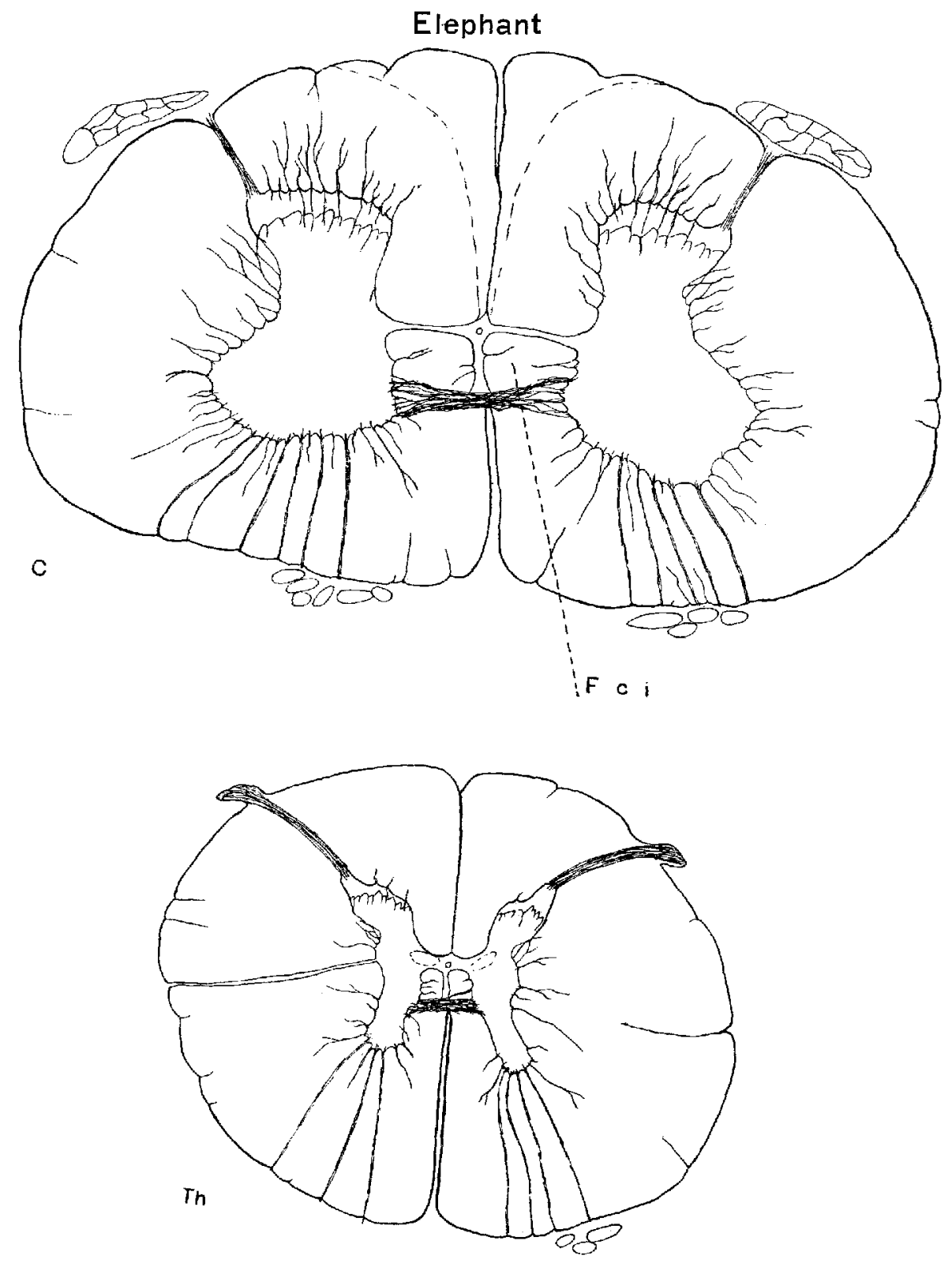

1 

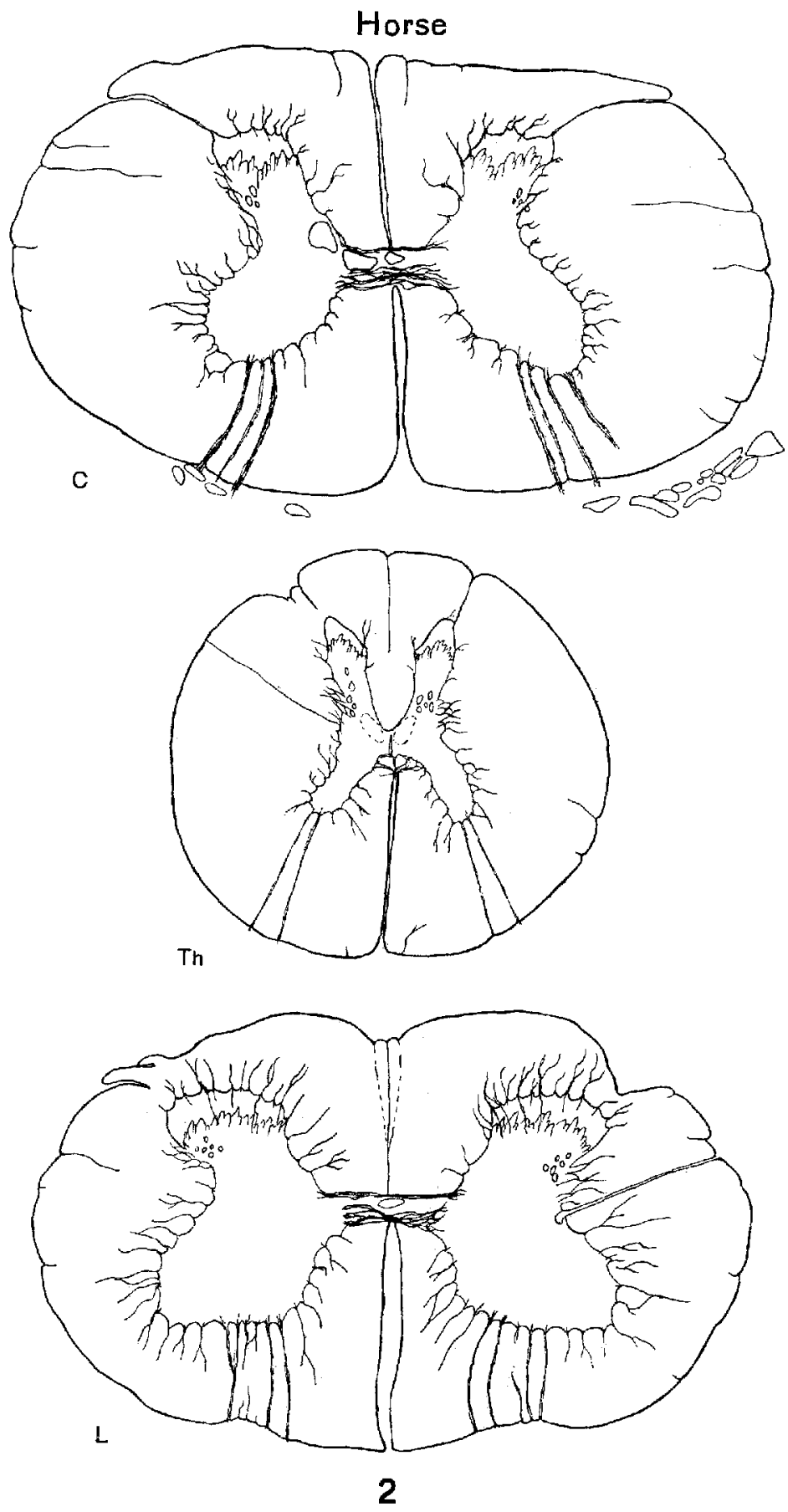

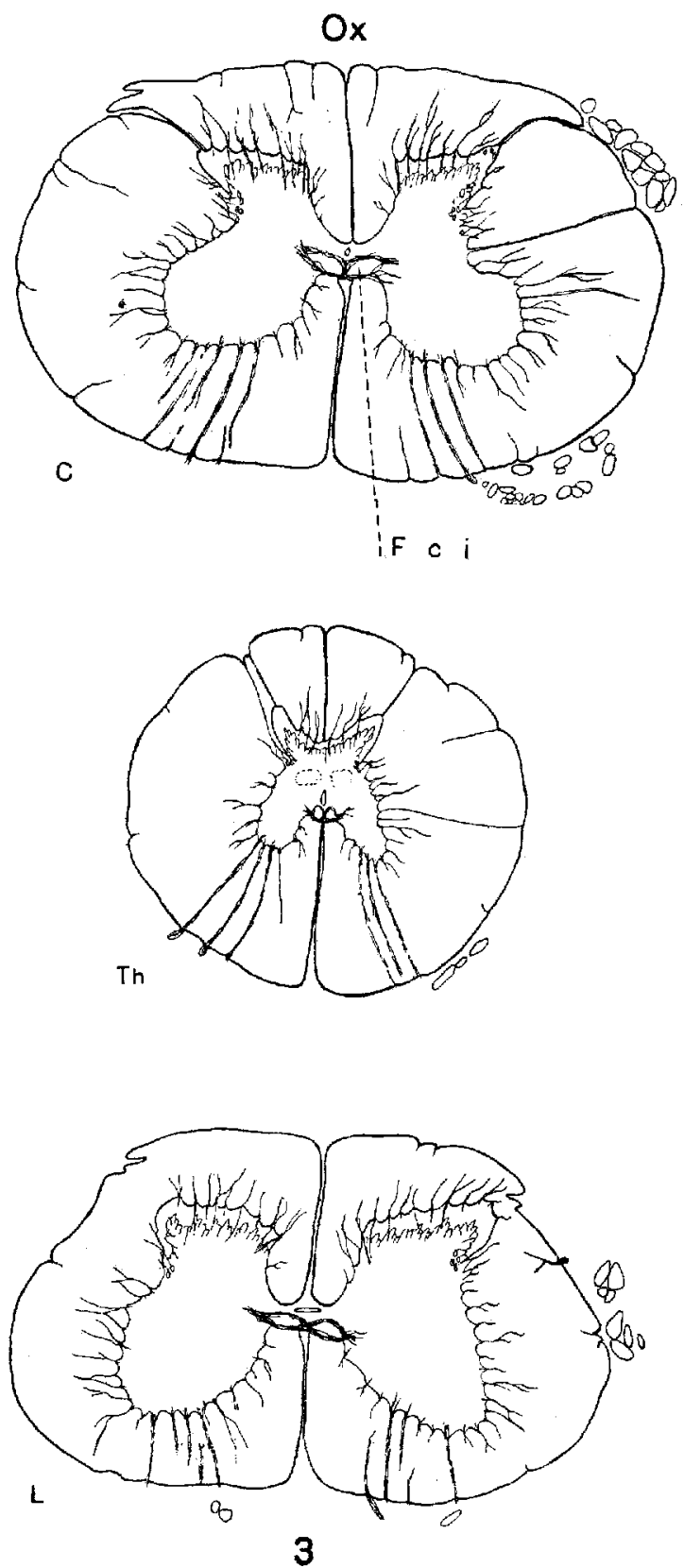
PRINCIPAL REGIONS OF SPINAL CORD

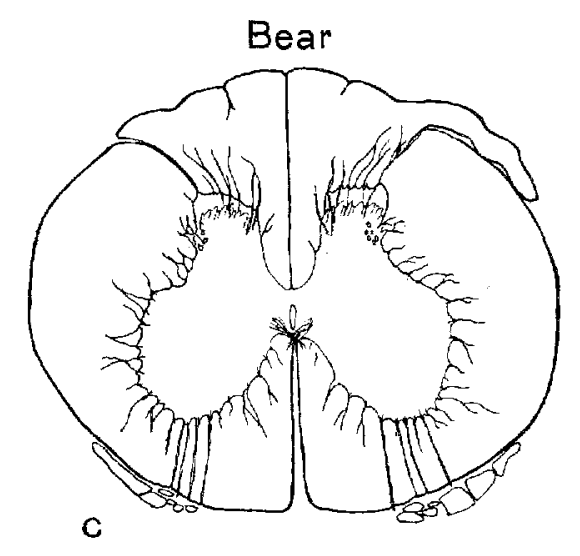

PEARL BRIGga BULLARD
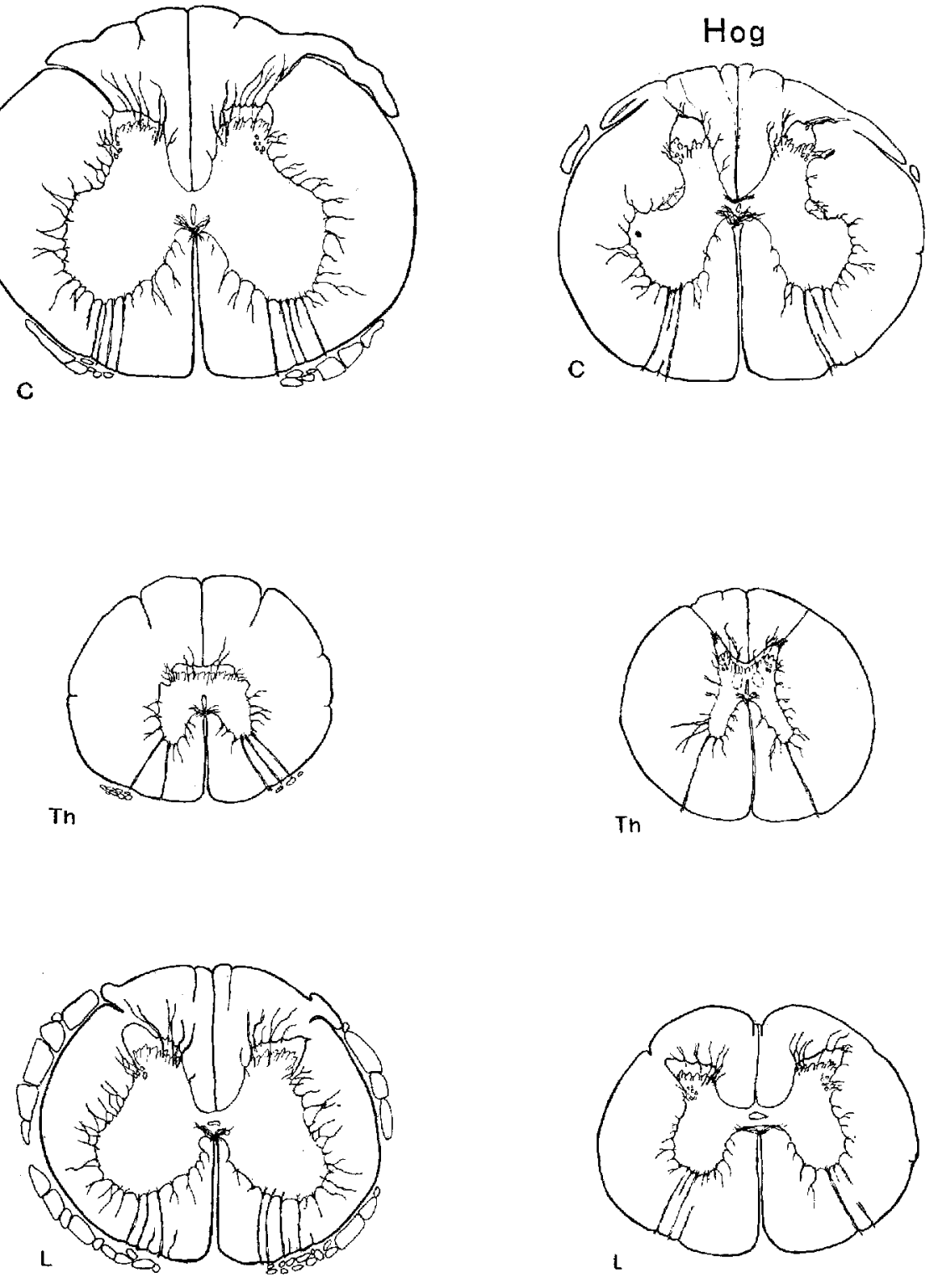

4

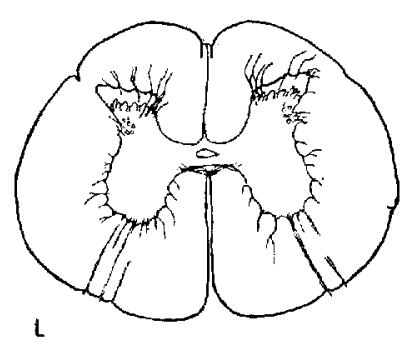

5 

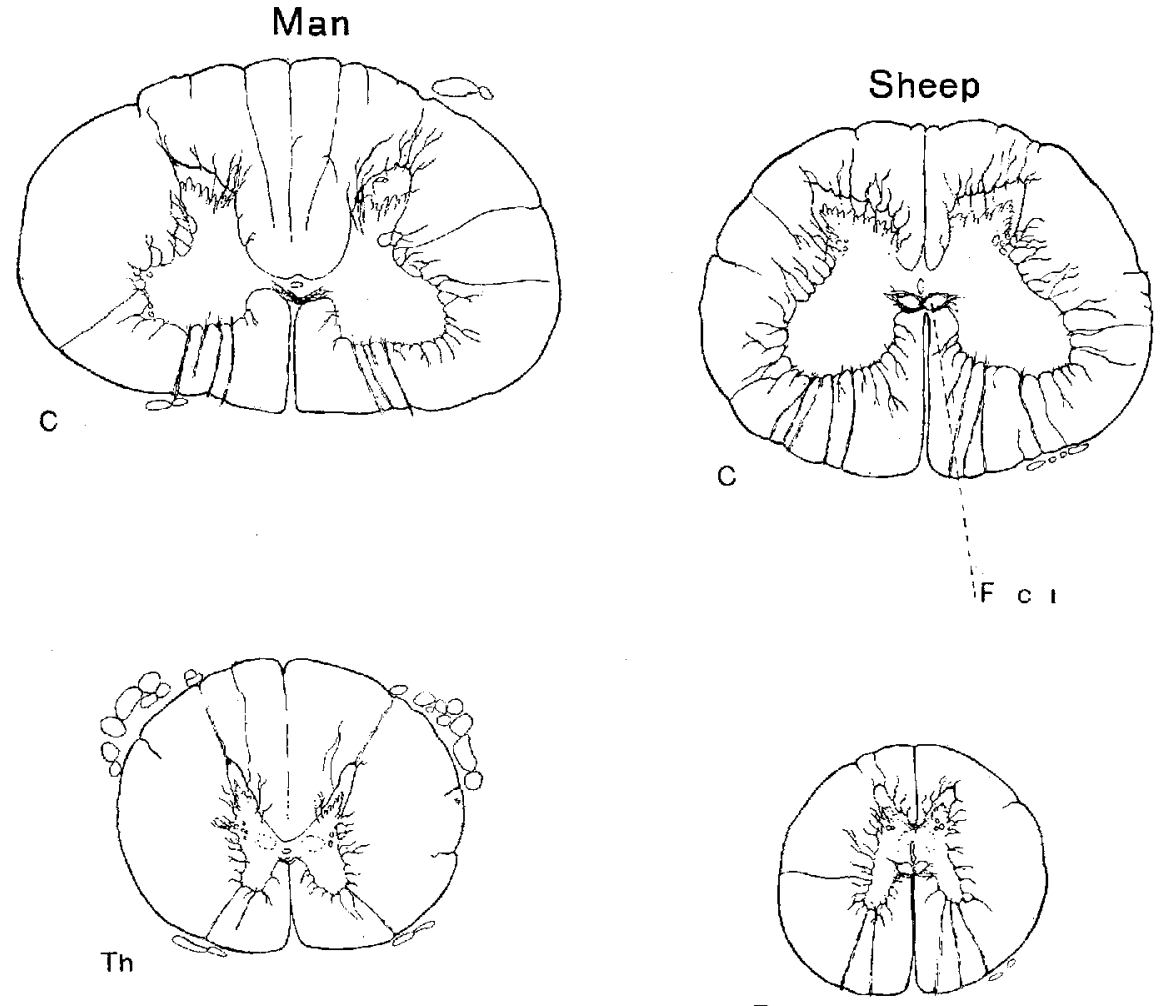

Th
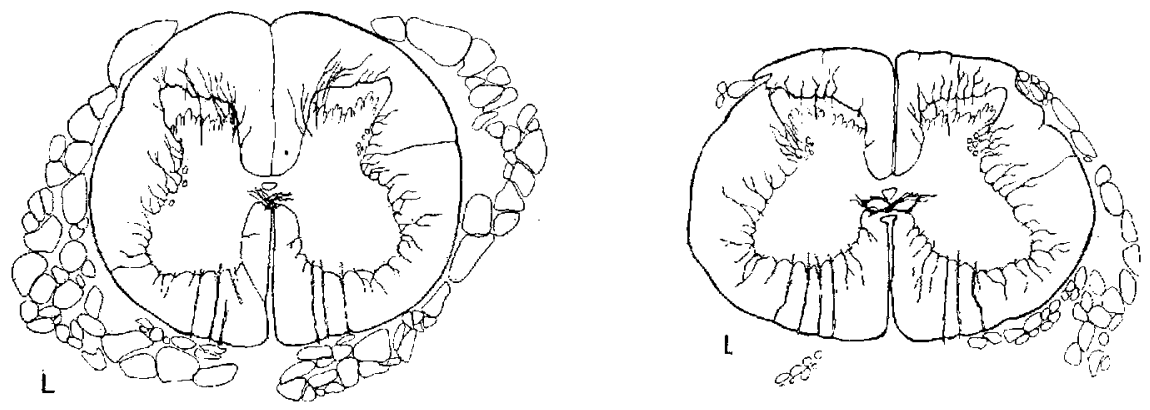

6 
PLATE 6
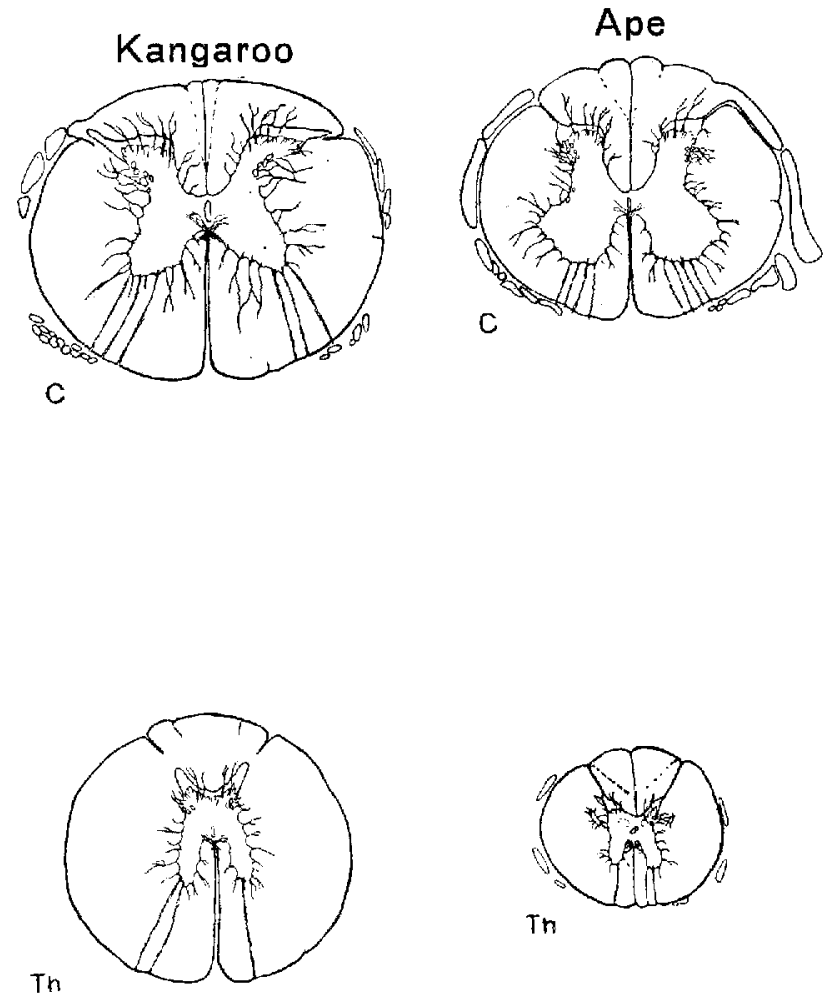

Tn
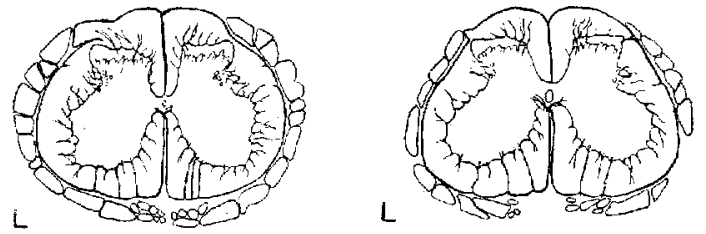

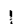

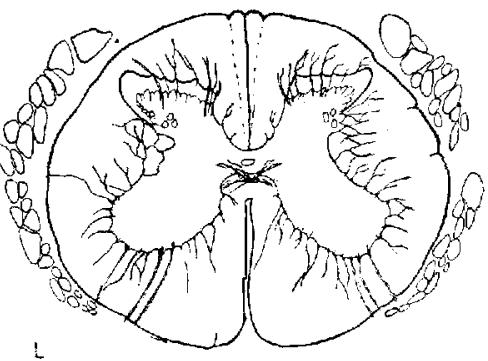

8
PRINCIPAL REGIONS OF SPINAL CORD pearl briggs bullard
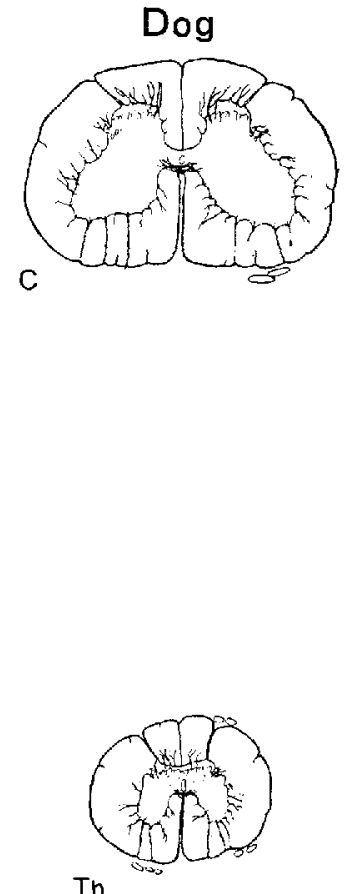

L

9
10 

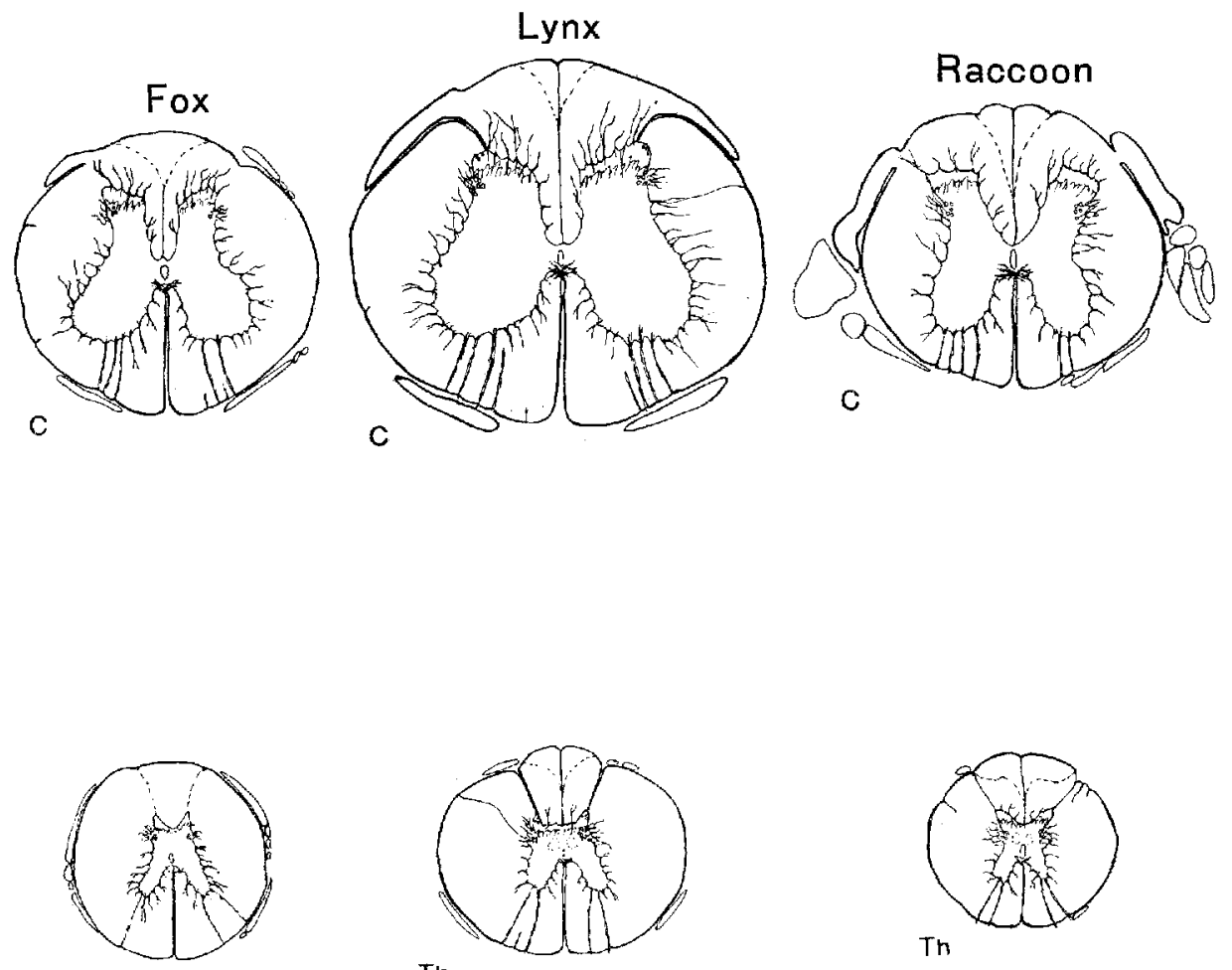

Th
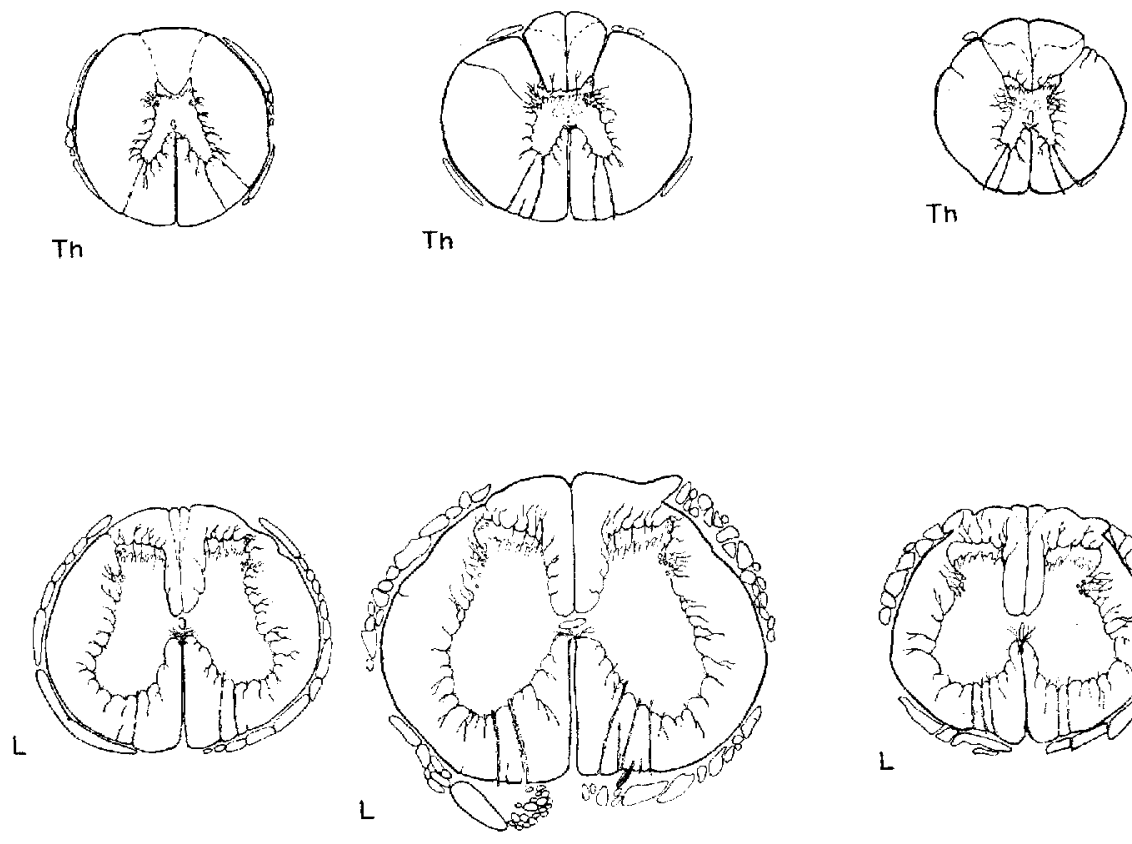

11

12

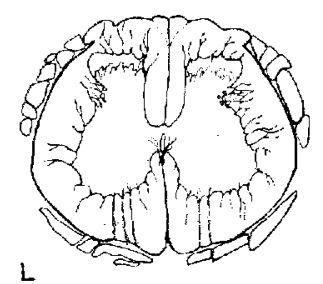

13 

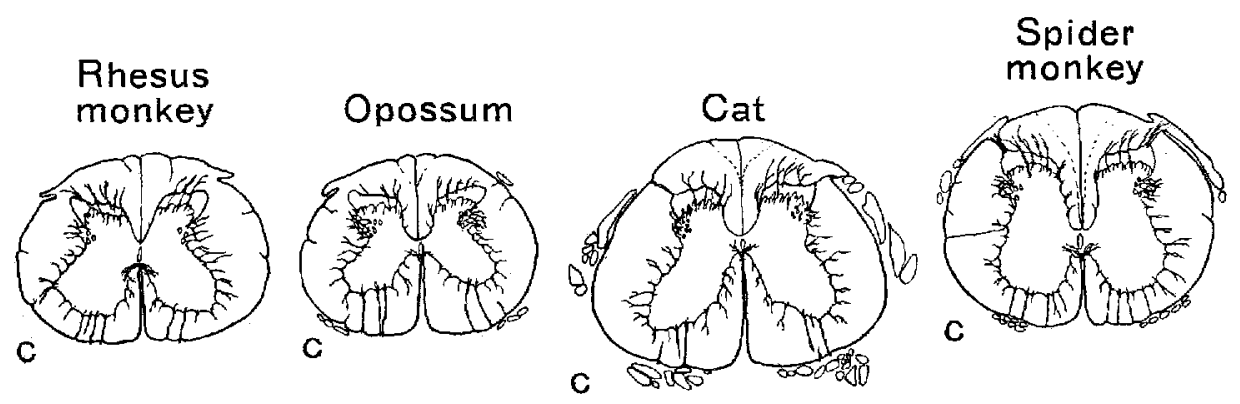

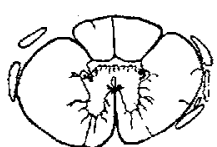

Th

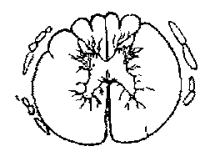

Th

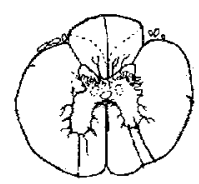

Th

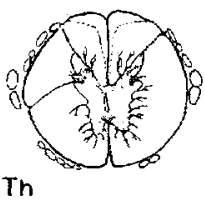

Th

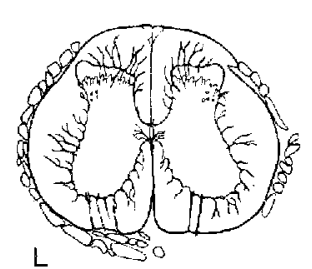

16

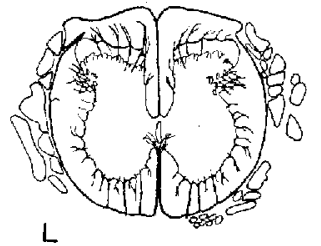

17 
PRINCIPAL REGIONS OF SPINAL CORD

PEARL BRIGGS BULLARD
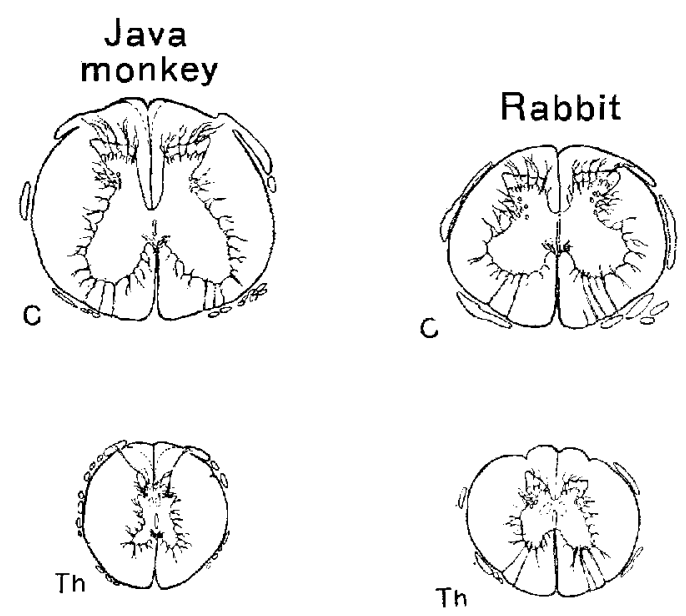

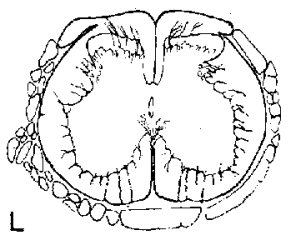

18
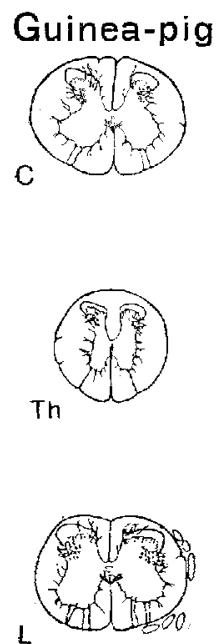

21

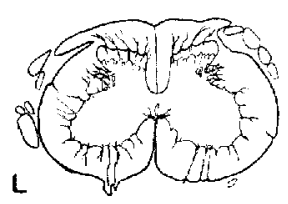

19
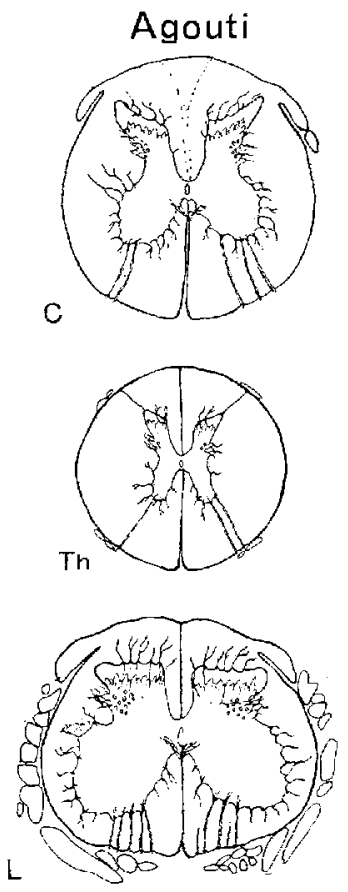

20
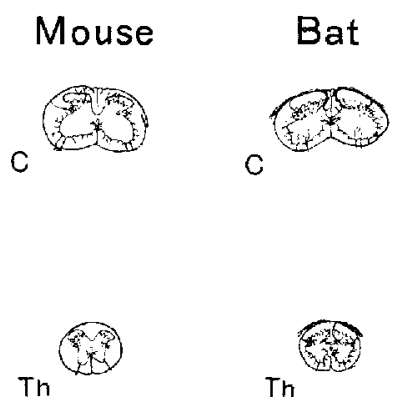

$\mathrm{L}$

$\mathrm{L}$<smiles>C1=CC2CC1CN2c1ccccc1</smiles>

24 